\title{
A Study of American Zoning Board Composition and Public Attitudes Toward Zoning Issues
}

\author{
Jerry L. Anderson* \\ Aaron E. Brees** \\ Emily C. Reninger $\dagger$
}

\section{Introduction}

In the United STATES, MANY IMPORTANT LAND USE DECISIONS are made, at least in the first instance, by local administrative bodies composed of citizens appointed by the mayor or city council. Although the names and responsibilities of these groups vary somewhat, they are traditionally designated the Planning and Zoning (P\&Z) commission and the Board of Zoning Adjustment or Zoning Appeals (BZA). Under the Standard State Zoning Enabling Act, ${ }^{1}$ used as the model for the majority of state zoning systems, ${ }^{2}$ the P\&Z commission formulates the city's comprehensive plan, which serves to guide future land use planning, and recommends to the city council specific zoning classifications for each district and amendments thereto. ${ }^{3}$ The BZA, on the other hand, makes decisions on variances and special use permits, providing the system with necessary flexibility. ${ }^{4}$ This article will refer to these two bodies collectively as "zoning boards."

\footnotetext{
*Richard M. and Anita Calkins Distinguished Professor of Law, Drake University Law School; Visiting Professor of Law, Stetson University College of Law (2007-08). Professor Anderson thanks Professor Bob Ellickson for his insightful comments, Derek Goodwin (Stetson '08) for his research assistance and Susan Anderson for her assistance in crunching the numbers. In addition, Professor Anderson thanks the Stetson law faculty for helpful comments on a presentation of this article.

**J.D., Drake University Law School (2007).

$\dagger$ J.D., Drake University Law School (expected 2009).

1. Standard State Zoning Enabling Act (1926), available at http://myapa. planning.org/growingsmart/pdf/SZEnablingAct1926.pdf [hereinafter "SSZEA"].

2. Ruth Knack, Stuart Meck, \& Israel Stollman, The Real Story Behind the Standard Planning and Zoning Acts of the 1920s, Land Use L. \& Zoning Dig. 3, 8 (Feb. 1996) (citing Department of Commerce study noting that 35 states adopted legislation modeled after SSZEA).

3. Douglas W. Kmiec, Zoning and Planning Deskbook $\$ 4: 3$ (2d ed. 2007).

4. SSZEA, supra note $1 \S 7$ (enumerating BZA functions); KMIEC, supra note 3 $\S 4: 15$.
} 
In some instances, the zoning board makes the final decision on such important matters as special use permits or variances. In other instances, such as zoning amendments, the board's decision is merely advisory and must be approved by the city council. Even in those cases, however, the board's recommendation typically wields significant influence and authority. As discussed in Section II, courts accord zoning board decisions (and city council decisions based on zoning board recommendations) a presumption of validity and employ a deferential standard of review. The deference accorded to zoning board decisions, however, is based in large part on the premise that they are neutral administrative bodies. Unfortunately, that may not be the case.

In fact, many sense that zoning boards often make land use decisions based on extra-legal factors, undermining their legitimacy. ${ }^{5}$ The significance of the property interests at stake in these decisions heightens the potential for corruption, favoritism, and bias. ${ }^{6}$ Conflict of interest provisions, even where they exist, typically do little to address generalized or systemic bias problems. ${ }^{7}$ Instead, the best way to reduce the potential for bias may lie in the appointment process: selecting a broad cross-section of disinterested citizens to zoning boards should ensure both that decisions are fair and that they are perceived by the public to be so.

Even in the formative years of comprehensive planning, scholars recognized that, because zoning boards wielded such power, it was important to ensure that they fairly represented the community. In 1937, Dr. Robert Walker conducted a survey of thirty-one of the largest cities in the country, to determine the occupations of their planning commission members. ${ }^{8}$ The results disturbed him: about $80 \%$ of commission members were drawn from what he called the "professional and technical" class, including business owners, lawyers, architects, engineers, and realtors. ${ }^{9}$ Of course, he recognized legitimate reasons for the prevalence of certain occupations. ${ }^{10}$ Commissions tended to include lawyers, for exam-

5. Mark W. Cordes, Policing Bias and Conflicts of Interest in Zoning Decisionmaking, 65 N.D. L. REv. 161, 162 (1989) (describing ad hoc, "dealmaking" nature of zoning decisions).

6. See, e.g., Evans v. United States, 504 U.S. 255, $257-58$ (1992) (discussing bribery in a zoning matter); see generally Robert C. Ellickson \& Vicki L. Been, LAND UsE Control, at 341-49 (2d ed. 2000) (detailing proof and perceptions of "dealmaking" and corruption in zoning).

7. Cordes, supra note 5, at 174-89 (concluding that conflict of interest rules applicable to zoning are insufficient); Jerry L. Anderson \& Erin Sass, Is the Wheel Unbalanced? A Study of Bias on Zoning Boards, 36 Urb. LAw. 447, 450-52 (2004) (same).

8. Robert A. Walker, The Planning Function In Urban Government 150 (Univ. of Chicago Press, 2d ed. 1950).

9. Id at 151 .

10. Id. 
ple, because numerous legal issues arose in commission activities. They included business owners because economic development was a central purpose of planning and, especially in the early days of comprehensive land use control, the commission needed to ensure its decisions would be accepted by civic leaders. ${ }^{11}$ Architects, planners, and builders provided the necessary expertise concerning planning options and the potential effects or feasibility of various restrictions. ${ }^{12}$ Nevertheless, Walker was concerned that the resulting commission membership failed to represent a cross-section of the community, and that blue-collar interests, in particular, were almost entirely excluded from the decision-making process. ${ }^{13}$ Moreover, Walker believed that business and professional members would be more likely to favor expansion and development, neglecting the point of view of what he called "the ordinary citizen," who did not stand to benefit directly from development activity. ${ }^{14}$

For this article, we replicated Walker's study, to determine whether seventy years later, zoning boards in the United States continue to be populated primarily by white-collar members, especially those tied to development and business interests. The study is more comprehensive than Walker's; we gathered data on the occupational composition of both the P\&Z commission and the BZA for 137 of the nation's largest cities. In total, we analyzed the occupations of 442 BZA members and $982 \mathrm{P} \& Z$ commission members. The results, discussed in Section III below, confirm that these boards have not changed much from Walker's 1937 study: board members continue to be drawn overwhelmingly from white-collar occupations and thus fail to represent a real cross-section of the community. In addition, zoning boards continue to be dominated by a few types of occupations: business owners, developers, attorneys and politicians. Thus, the "ordinary citizen" described by Walker is still not represented.

Of course, the suggestion that zoning boards are heavily populated with interest group representatives is an old idea and hardly surprising. ${ }^{15}$ Historically, the design of zoning boards populated by "experts" sprang from Progressives' faith in professionals and contempt for ordinary politics.$^{16}$ City officials may believe that the technical nature of the boards' functions requires expertise these professionals can provide. The political nature of the zoning boards' function may inevitably lead

\footnotetext{
11. Id.

12. Id.

13. WALKER, supra note 8, at 153.

14. Id. at 151-52.

15. See, e.g., Richard F. Babcock, The Zoning Game, passim (1966).

16. Terence Ball, The Authority of Experts, 13 ConTEMP. Soc. 743, 744 (Nov. 1984) (book review).
} 
to the involvement of those with vested interests in the process. ${ }^{17} \mathrm{In}$ deed, one view suggests that achieving a rough balance between interest groups may be preferable to attempting to find elusive and perhaps illusory "ordinary citizens," who frankly may be less motivated to undertake the tedious work of these panels.

These results, however, raise the question of whether the occupational skew makes a real difference in the planning and zoning decisionmaking process. If cities could achieve a more representative board composition, how would planning and zoning decisions be affected? In order to address that question, we conducted a survey of citizens to solicit their opinions on various controversial land use issues. By categorizing the results according to the respondent's occupation and other demographic characteristics, we sought to determine whether the views of the "ordinary citizen," as Walker put it, differ from the views of the typical representative of the professional, managerial, and technical class. We also explored how other demographic factors, such as race, age, income or educational level, correlate with zoning attitudes. In Section IV below, we discuss the results of this survey of public attitudes toward zoning issues.

Ultimately, the results of these studies lead us to recommend that those who appoint members to zoning boards strive to include a broad cross-section of citizens to ensure that all views are presented. We are cognizant that certain natural tendencies lead to the appointment of white-collar board members and we recognize that those members provide valuable, even indispensible, functions on these boards. Nevertheless, the changing role of zoning boards, combined with the availability of professional planning staff and legal counsel now may allow for a broader group of citizens to be included. In the end, we anticipate that more representative boards will lead to better decision-making and greater community acceptance of board decisions. Unless zoning boards begin to at least approximate the ideal of a neutral administrative body, courts may need to re-think the deference they typically grant to board decisions.

\section{Zoning Boards in the United States}

State zoning systems today come in many varieties, making generalizations difficult. The basic structure in most states, however, is based on

17. See Don T. Allensworth, The Political Realities of Urban Planning 79-80 (1975) (stating that interest groups are heavily represented on zoning boards). 
two uniform acts drafted by committees appointed by the federal government in the 1920s. The State City Planning Enabling Act (SCPEA), published in 1928, gave states model legislation to authorize municipal land use planning, including the adoption of a comprehensive plan. ${ }^{18}$ The Standard State Zoning Enabling Act (SSZEA) of 1924, drafted by the Advisory Committee on Zoning appointed by U.S. Commerce Secretary Herbert Hoover, became the model for the zoning system in use in most states. ${ }^{19}$

Section 6 of the SSZEA provided that the initial zoning ordinance, including the location of the various districts, should be drafted by a commission made up of "an outside body of representative citizens." 20 Similarly, the SCPEA provided for an independent citizen board, called a planning commission, which would be responsible for formulating and revising the jurisdiction's comprehensive plan. ${ }^{21}$ In most states, these planning and zoning duties now have been combined in one P\&Z commission. ${ }^{22}$ While the SSZEA contemplated that the zoning commission would be temporary, ${ }^{23}$ today the $\mathrm{P} \& \mathrm{Z}$ commission is a permanent fixture typically responsible for approving subdivision plats and site plans and recommending zoning amendments. ${ }^{24}$

Most jurisdictions provide that the $\mathrm{P} \& \mathrm{Z}$ commission is advisory in nature; its recommendations are subject to review and approval by the local legislative body. ${ }^{25}$ In some states, however, $\mathrm{P} \& \mathrm{Z}$ decisions are accorded more weight than mere recommendations. For example, zoning commission decisions in Connecticut, on everything from the adoption and amendment of zoning regulations to site plan approval, are final. ${ }^{26}$ In other states, such as Kentucky, the planning commission recommendation regarding a zoning amendment becomes law unless the local legislative body acts to overrule it by majority vote within ninety days. ${ }^{27}$ In other states, commission decisions require a supermajority of the

18. Standard City Planning Enabling Act (Dept. of Commerce 1928), available at http://myapa.planning.org/growingsmart/pdf/CPEnablingAct1928.pdf.

19. See SSZEA, supra note 1; see also KMIEC, supra note 3, § 2.5, at 2-15; DANIEL R. MANDELKer, LAND Use LAW $\S 4.15$ (4th ed. 1997) (stating that all state zoning legislation is based on SSZEA).

20. SSZEA, supra note $1 \S 6$, n.39.

21. SCPEA, supra note $18 \S 6$.

22. See, e.g., Mo. Rev. Stat. $\S \S 89.330,89.340$ (2008).

23. See SSZEA, supra note $1 \S 6 \mathrm{n} .43$ (stating that continuing the commission as a permanent body "may not be desirable").

24. Kmiec, supra note 3, at § 4:3; see, e.g., Mo. Rev. Stat. § 89.370-410 (2008).

25. KMIEC, supra note 3, at $\S \S 4: 2,4: 6$.

26. Conn. Gen. Stat. \$ 8-1-8-3 (2008).

27. Ky. Rev. Stat. AnN. § 100.211 (West 2008). 
council to override. For example, in Indiana, the planning commission's adverse recommendation regarding a petition to rezone a particular tract of land requires a two-thirds vote of the local legislative body to overturn. ${ }^{28}$ Even when their decisions are not final, $P \& Z$ opinions are typically very influential, especially if the board is viewed as a neutral, expert body insulated from political influence. ${ }^{29}$ Moreover, on judicial review, the recommendation of the $\mathrm{P} \& \mathrm{Z}$ commission can be an important factor in determining the reasonableness of the council's decision. ${ }^{30}$ Thus, the commission wields important, if not always plenary, authority in the planning and zoning process.

Section 7 of the SSZEA provided for a board of adjustment, again appointed by the local legislative body, to be responsible for granting "special exceptions" to the zoning ordinance..$^{31}$ In particular, the BZA has the authority to grant variances from regulations in cases of "unnecessary hardship." 32 Under the SSZEA, the BZA has the final decision on these matters, with an appeal directly to the state circuit court. ${ }^{33}$ In some states, BZA decisions may be appealed in the first instance to the city council. ${ }^{34}$

Judicial review of zoning decisions is extremely deferential. Courts accord local legislative judgments a presumption of validity 35 and decline to overturn city council zoning decisions unless they are arbitrary and capricious or unreasonable. ${ }^{36} \mathrm{P} \& \mathrm{Z}$ commission decisions that do not go through city council ratification are given similar deference. ${ }^{37}$ Courts

28. IND. CoDE $§ 36-7-4-609$ (2008); see City of Anderson v. Irving Materials, Inc., 530 N.E.2d 730, 732 (Ind. 1988).

29. AllensworTh, supra note 17, at 79 (stating that planning board decisions carry considerable weight due to perception of independence).

30. See, e.g., Walker v. Indian River County, 319 So. 2d 596, 599 (Fla. Dist. Ct. App. 1975).

31. SSZEA, at 11.

32. SSZEA, at 11; see, e.g., Mo. Rev. Stat. § 89.090 (2008).

33. SSZEA, at 11; see, e.g., Mo. Rev. Stat. \$ 89.110 (2008).

34. See, e.g., N.J. Stat. Rev. 40:55D-17 (West 2008).

35. Drew v. City of Hattiesburg, 904 So. 2d 138, 140 (Miss. 2005); Lapp v. Village of Winnetka, 833 N.E.2d 983, 998 (Ill. App. Ct. 2005).

36. See, e.g., Mayor of Ridgeland v. Estate of Lewis, 963 So. 2d 1210, 1214 (Miss. Ct. App. 2007) (discussing arbitrary and capricious or reasonableness review of zoning amendment decision); Bradley v. Payson City Corp., 70 P.3d 47, 50 (Utah 2003) (stating that zoning amendment decisions are upheld unless "arbitrary and capricious or otherwise illegal").

37. See, e.g., Auger v. Strafford, 931 A.2d 1213, 1215 (N.H. 2007) (describing the reasonableness standard for review of planning board decision); Markland v. Jasper County Planning \& Dev. Dep’t., 829 N.E.2d 92, 96 (Ind. Ct. App. 2005) (applying the "clearly erroneous" standard and presumption of correctness to planning board decisions); Harris v. Zoning Comm'n of New Milford, 788 A.2d 1239, 1250 (Conn. 2002) (stating that courts will not disturb zoning commission decisions unless they are clearly contrary to law or there was an abuse of discretion). 
also accord BZA decisions a presumption of validity ${ }^{38}$ and review them using a narrow arbitrary and capricious or abuse of discretion standard..$^{39}$ Other courts use a reasonableness standard, which they describe as similarly deferential. ${ }^{40}$ Because decisions on variances or special exceptions may be characterized as "quasi-judicial," courts generally require substantial evidence to support the board's decision.$^{41}$ Of course, questions involving pure interpretations of law are typically reviewed de novo. ${ }^{42}$

Deference to the decisions of these zoning bodies is based on a variety of theories. When a city council determination, such as a zoning amendment, is involved, courts accord that decision the deference to which legislative judgments of elected political bodies are regularly entitled..$^{43}$ For similar reasons, courts defer to planning and zoning commission decisions that are legislative in nature. ${ }^{44}$

For decisions that are not legislative, courts treat the zoning body as an administrative agency, giving their decisions the same kind of deference accorded agency determinations under state administrative procedure acts. ${ }^{45}$ Some of the earliest cases involving the review

38. See generally 2 James Metzenbaum, The Law of Zoning 931-46 (2d ed. 1955) (collecting cases giving presumption of validity to BZA decisions); see, e.g., State ex rel. Ziervogel v. Washington County Bd. of Adjustment, 676 N.W.2d 401, 405 (Wis. 2004) (stating that the presumption of validity must be accorded to BZA decisions); Ackman v. Bd. of Adjustment for Black Hawk County, 596 N.W.2d 96, 106 (Iowa 1999).

39. See, e.g., Ziervogel, 676 N.W.2d at 405-06 (Wis. 2004) (stating that a BZA decision will be overturned only when "its action was arbitrary, oppressive, or unreasonable and represented its will and not its judgment"); Conley v. Brookhaven Zoning Bd. of Appeals, 353 N.E.2d 594, 597 (N.Y. 1976) (stating that the standard for a BZA appeal is "illegality, arbitrariness or abuse of discretion").

40. Ackman, 596 N.W.2d at 106.

41. Weaverville Partners LLC v. Weaverville Zoning Bd. of Adjust., 654 S.E.2d 784, 787 (N.C. Ct. App. 2008) (stating that the board's decision was quasi-judicial and providing the substantial evidence standard); Kramer v. Bd. of Adjustment, Sea Girt, 212 A.2d 153 (N.J. 1965) (same).

42. Ziervogel, 676 N.W.2d at 406; Brown v. Sandy City Board of Adjustment, 957 P.2d 207, 210 (Utah Ct. App. 1998) (stating that the board's interpretation of a statute or ordinance is not given deference).

43. See, e.g., Red Roof Inns, Inc. v. City of Ridgeland, 797 So. 2d 898, 900 (Miss. 2001) (stating that a city council's rezoning decision is a legislative act entitled to deference).

44. See Arnold Bernhard \& Co., Inc. v. Planning and Zoning Comm'n of Westport, 479 A.2d 801, 807 (Conn. 1984). While there was some movement toward classifying zoning amendments as quasi-judicial and therefore subject to heightened scrutiny, see Fasano v. Bd. of County Comm'rs of Washington County, 507 P.2d 23, 26 (Or. 1973), this view did not catch on. William B. Stoebuck \& Dale A. Whitman, The Law of Property 620 (3d ed. 2000).

45. Hampton House Mgt. Co. v. Brimfield Twp. Bd. of Zoning Appeals, 2007 WL 4226673, at *3 (Ohio Ct. App. Nov. 30, 2007); People's Counsel for Baltimore County v. Surina, 929 A.2d 899, 910 (Md. 2007). 
of zoning board decisions used the administrative agency rationale to establish a deferential standard. Shortly after New York City adopted the nation's first comprehensive zoning ordinance in 1916, New York courts were faced with appeals from the decisions of these unelected bodies, which wielded enormous power over private property. In one early decision, Falvo v. Kerner, the court noted that the board of zoning appeals determination "was an administrative function which should not be interfered with by the courts in the absence of proof that the board ... abused the discretion with which it was clothed by the ordinance creating it." ${ }^{46}$

Although unelected, the zoning board is deemed a "public body" whose decisions are entitled to deference. ${ }^{47}$ Moreover, as a policy matter, courts believe citizen boards are in the best position to decide local land use questions. ${ }^{48}$ As the New Jersey Supreme Court noted in an early case adopting a deferential standard:

Local officials who are thoroughly familiar with their community's characteristics and interests and are the proper representatives of its people are undoubtedly the best equipped to pass initially on such applications for variance. And their determinations should not be approached with a general feeling of suspicion, for as Justice Holmes has properly admonished: 'Universal distrust creates universal incompetence.' ${ }^{\text {'9 }}$

However, even in the early cases, the New York courts realized that the significant power given to these local bodies could be easily abused; therefore, they attempted to give the review process some teeth by requiring that boards adequately support their decisions. Thus, in a 1927 case, the New York Court of Appeals overturned a variance granted for building a garage based on "unnecessary hardship," where the only evidence was that variances had been granted before in similar circumstances. ${ }^{50}$ The court refused to affirm without evidence of hardship on the record, stating "[t]here has been confided to the board a delicate

46. Falvo v. Kerner, 222 A.D. 289, 291 (N.Y. App. Div. 1927); see also People ex rel. Werner v. Walsh, 212 A.D. 635,639 (N.Y. App. Div. 1925) (stating that a board of appeals' exercise of "administrative function" should not be overturned absent discrimination or grave abuse of discretion).

47. See, e.g., C. Miller Chevrolet, Inc. v. City of Willoughby Hills, 313 N.E.2d 400, 403-04 (Ohio 1974) (stating that the BZA is a "public body" whose decisions are therefore entitled to a presumption of validity).

48. Julian Conrad Juergensmeyer \& Thomas E. Roberts, Land Use PlanNING AND CONTROL LAW 258 (1998) (stating that the reasons courts adopt deferential standards include the board's expertise and familiarity with local conditions).

49. Ward v. Scott, 105 A.2d 851, 855 (N.J. 1954) (quoting Graham v. United States, 231 U.S. 474, 480 (1913); see also Kramer, 212 A.2d at 169.

50. People ex rel. Fordham Manor Reformed Church v. Walsh, 155 N.E. 575, 578 (N.Y. 1927). 
jurisdiction and one easily abused. Upon a showing of unnecessary hardship, general rules are suspended for the benefit of individual owners and special privileges established.... Disclosure is the antidote to partiality and favor." ${ }^{51}$

Aside from ensuring that their decisions are adequately supported, however, courts have found few methods of ensuring board impartiality, because their decisions are often inherently political. For that reason, the Maryland Supreme Court found that vesting the board of zoning appeals with the power to grant variances from zoning ordinances was an unconstitutional delegation of an essentially legislative function. ${ }^{52}$ The court warned that the system was fraught with the danger of favoritism and bias:

It is an unequal and partial law that permits an administrative board, in its discretion, to free a specific piece of property from universal regulations and restrictions which are imposed for the general benefit of all property within the defined area of which the freed property is a part. ... [I]t partakes of the nature of special legislation for a private interest, and hence finds no basis in the general welfare. ... Abstractly considered there is much force in the argument that the board of zoning appeals should have powers of variation and suspension to correct excessive burdens imposed by the enforcement of the regulations in the several districts of a comprehensive zoning system; but, in its concrete result, this rule of expediency to relieve individual hardship is productive of inequality, popular discontent, and inferences or charges of favoritism. ${ }^{53}$

Given this susceptibility to at least the appearance of bias and the importance of the property interests at stake, it seems crucial to ensure that the citizen zoning boards truly represent a cross-section of the community, rather than being populated with those with a vested interest in the development process. Indeed, the deference courts give to these unelected boards is largely grounded in the belief that they are neutral administrative bodies, composed of "the proper representatives" of the people, as the New Jersey Supreme Court put it. ${ }^{54}$ In reality, however, zoning boards often do not comport with this ideal, as the following section details.

51. Id.

52. Sugar v. North Baltimore Methodist Protestant Church, 165 A. 703, 707 (Md. 1933).

53. Id. at 706-07. Most courts find no improper delegation, as long as the administrative decisionmaker has been provided with sufficient standards. See generally KMIEc, supra note 3, at $\S 4: 19$.

54. Ward v. Scott, 105 A.2d 851, 855 (N.J. 1954). Similarly, the SSZEA speaks of the zoning commission as "an outside body of representative citizens." SSZEA, supra note 1 , at 9 n.39. 


\section{National Study of Zoning Board Occupational Composition}

For this article, a research team from Drake University Law School surveyed the zoning boards of the most populous cities in the country, to determine whether the skew toward white-collar and development-related board members, which Robert Walker identified in 1937, persists in modern zoning boards. This study builds on the results of two more limited surveys recently conducted by Drake researchers. The first study examined the occupations of zoning board members in Iowa municipalities. ${ }^{55}$ The results indicated that, especially in larger cities, Iowa zoning boards were overwhelmingly populated with white-collar occupants: although less than a third of Iowa's citizens held professional, managerial and technical jobs, they comprised about $74 \%$ of BZA members and $80 \%$ of P\&Z members in Iowa cities with populations over $25,000 .{ }^{56}$ Moreover, the study found that boards typically included many individuals who had a direct interest in land development-realtors, lenders, builders, contractors, and architects, for example - and that some boards were dominated by those with such interests. ${ }^{57}$ About $30 \%$ of all Iowa zoning board members held jobs directly related to development activity, and another 16$20 \%$ could be said to be at least indirectly benefitted by increased development. ${ }^{58}$

A follow-up study examined zoning boards in Oregon, to determine the efficacy of legislation restricting the occupational composition of zoning boards. ${ }^{59}$ Oregon attempts to achieve broader occupational distribution by prohibiting the selection of more than two P\&Z commission members from the same occupational category ${ }^{60}$ Moreover, no more than two of the commission members may be "engage[d] principally in the buying, selling or developing of real estate." ${ }^{61}$ The study revealed that these restrictions did not remedy the skew toward whitecollar occupations. In cities with populations greater than 25,000, over $90 \%$ of Oregon's P\&Z commissioners were drawn from the profes-

55. Anderson \& Sass, supra note 7.

56. Id. at 464 .

57. Id. at 467.

58. Id. at $465-68$.

59. Jerry L. Anderson \& Daniel Luebbering, Zoning Bias II: A Study of Oregon's Zoning Commission Composition Restrictions, 38 URB. LaW. 63 (2006).

60. Or. Rev. Stat. § 227.030(4) (2007).

61. Id. 
sional, technical, or managerial professions. ${ }^{62}$ The law did reduce the number of members with a direct interest in development; nevertheless, we identified about a fourth of board members who had occupations directly related to development and several cities with boards dominated by development interests. ${ }^{63}$

While these first two studies were instructive, we were unable to make any judgments about the composition of zoning boards nationwide. Therefore, for this paper we undertook a comprehensive survey of all major cities in the United States, to determine definitively who sits on the nation's zoning boards.

\section{A. Study Design}

In fall 2006, we sent a survey to a selection of large cities across the country, requesting information on the occupations of members of their P\&Z commissions and BZA. The selected cities included: 1) the one hundred most populous cities in the country, according to the 2000 census results, and 2) the five most populous cities in every state, in order to ensure geographic diversity. We received 119 usable survey responses from this mailing. Because some of the largest cities in the country declined to respond to the survey, we then gathered additional occupational information by searching the city government web pages of the most populous cities. We were ultimately able to obtain data for 137 major United States cities.

The subject cities ranged in size from New York City (population just over 8 million) to Cupertino, California (population just over 50,000) ${ }^{64}$ Most of the respondents were small to mid-size cities, but the respondents also represent a good sample of the larger cities. For example, we have data on eighteen out of the twenty-nine largest United States cities.

Table 1 shows the populations of the cities for which we were able to obtain data.

The survey includes occupational data for a total of 442 BZA members and $982 \mathrm{P} \& \mathrm{Z}$ commission members. The surveys identified fewer

62. Anderson \& Luebbering, supra note 59, at 72-73, Tables $3 \& 4$. In all cities surveyed, about $75 \%$ of board members are white-collar, about twice the percentage in the Oregon labor force. Id.

63. Id. at 76-77, Table 5.

64. U.S. Bureau of the Census, Census of Population and Housing (2006). Population data was taken from 2000 census and includes only the population within the city's corporate boundaries. Metropolitan area data may be much different, but is not relevant to our survey, which is based on boards with authority only within the city limits (although some boards have limited authority a short distance outside of city limits as well). 
Table 1: Respondent Cities

\begin{tabular}{lcl}
\hline City size & $\begin{array}{l}\text { Number of } \\
\text { respondents }\end{array}$ & Representative Cities \\
\hline $\begin{array}{l}\text { Very Large (pop. over } \\
\text { 500,000) }\end{array}$ & 18 & $\begin{array}{l}\text { New York, LA, Chicago, } \\
\text { Dallas, Jacksonville, } \\
\text { Nashville }\end{array}$ \\
$\begin{array}{l}\text { Large (pop. 250,000 } \\
\text { to 499,000) }\end{array}$ & 13 & $\begin{array}{l}\text { New Orleans, Las Vegas, } \\
\text { Tulsa, St. Louis, Pittsburgh, } \\
\text { Omaha }\end{array}$ \\
$\begin{array}{l}\text { Mid-size (pop. 100,000 } \\
\text { to 249,000) }\end{array}$ & 51 & $\begin{array}{l}\text { Birmingham, Durham, } \\
\text { Dayton, Glendale, Augusta, } \\
\text { Ft. Wayne } \\
\text { Small (pop. under 100,000) }\end{array}$ \\
& 55 & $\begin{array}{l}\text { Ogden, Beaverton, Appleton, } \\
\text { Santa Fe, Rapid City, Gulfport }\end{array}$ \\
\end{tabular}

BZA members for several reasons. Some states, such as Oregon, ${ }^{65}$ do not use a BZA, and in others, such as California, cities have the option of using a zoning administrator or the planning commission for typical BZA functions ${ }^{66}$ Moreover, in many cities the $\mathrm{P} \& \mathrm{Z}$ commission has more members than the city's BZA (Oklahoma City, for example, has nine P\&Z members, but only five BZA members). In addition, for the follow-up investigation of web site information for larger cities, we concentrated on P\&Z members' occupational data, which is more readily available on-line.

We asked each city to identify the occupation of each member of its P\&Z commission and BZA. We then classified the occupations using the Dictionary of Occupational Titles, published by the Department of Labor. ${ }^{67}$ This system classifies occupations into nine basic categories:

1. professional, technical, and managerial occupations;

2. clerical and sales occupations;

65. See Anderson \& Luebbering, supra note 59, at 67-68 (describing the Oregon system).

66. Cal. Gov. Code $\S 65901$ (providing that either the zoning administrator or BZA may issue conditional use permits or variances); Cal. Gov. Code $\S 65902$ (stating that if a city or county has neither BZA nor zoning administrator, the planning commission may exercise those functions); see, e.g., Sacramento City Code, Title 17 (describing the authority of the zoning administrator regarding variances, special permits and development plans).

67. U.S. Dep't of Labor, Dictionary of Occupational Titles (4th ed. 1991). 
3. service occupations;

4. agricultural, fishery, forestry, and related occupations;

5. processing occupations;

6. machines trades occupations;

7. benchwork occupations;

8. structural work occupations; and

9. miscellaneous occupations. ${ }^{68}$

For the purposes of summarizing our results, we combined the small numbers of individuals in categories 5-8 in one "Processing and Labor" category and placed anyone in the "Miscellaneous" category in the group that most closely fit their occupation. We also added a "Homemaker" category, which is not included in the Department of Labor classifications.

\section{B. Study Results}

The national data show that American zoning boards are overwhelmingly populated with members from white-collar occupations. As shown in Table 2, three-quarters of both P\&Z commissions and BZA are drawn from Professional, Technical and Managerial (PTM) occupations, over twice their representation in the overall workforce. Laborers are the most underrepresented group, occupying just $1-2 \%$ of the seats on these boards, despite making up almost a quarter of the employed population.

The Clerical/Sales group is closer to being proportionately represented, with $13 \%$ of P\&Z commission and $16 \%$ of BZA members, compared with their workforce percentage of $27 \%$. However, real estate agents comprised the largest segment of this group: on the $\mathrm{P} \& \mathrm{Z}$ commissions, there were fifty-four real estate agents out of the 111 clerical and sales members, and on the BZA, thirty-nine out of fifty-nine cleri$\mathrm{cal} / \mathrm{sales}$ members were real estate agents. Thus, outside of real estate agents, clerical and sales occupations are also significantly underrepresented. Agriculture is almost totally excluded, which is not surprising since there are few agricultural uses within the city limits of large municipalities. Nevertheless, the failure to include agricultural interests means that their unique perspective on issues like the conversion of farmland to development use is not considered in municipal land use decision-making. ${ }^{69}$

These numbers are remarkably consistent with Robert Walker's 1937 study, which found that $79.4 \%$ of large city planning and zoning

68. Id. at xviii.

69. See infra Part IV.D.1. (discussing zoning opinions of citizens with agricultural occupations). 
Table 2: Members by Occupational Category

\begin{tabular}{|c|c|c|c|c|c|}
\hline \multirow{2}{*}{$\begin{array}{l}\text { Occupational } \\
\text { Category }\end{array}$} & \multicolumn{2}{|c|}{ P \& Z Commission } & \multicolumn{2}{|c|}{ Board of Adjust. } & \multirow{2}{*}{$\begin{array}{l}\text { Percent of National } \\
\text { Workforce* }\end{array}$} \\
\hline & Members & Percent & Members & Percent & \\
\hline $\begin{array}{l}\text { Professional, } \\
\text { Technical, } \\
\text { Managerial }\end{array}$ & 790 & 80 & 333 & 75 & 34 \\
\hline $\begin{array}{l}\text { Clerical and } \\
\text { Sales }\end{array}$ & 111 & 11 & 69 & 16 & 27 \\
\hline Service & 36 & 4 & 20 & 5 & 15 \\
\hline $\begin{array}{l}\text { Processing, } \\
\text { Labor }\end{array}$ & 10 & 1 & 10 & 2 & 24 \\
\hline Agricultural & 5 & 1 & 1 & $<1$ & 1 \\
\hline Homemaker & 30 & 3 & 9 & 2 & $\mathrm{n} / \mathrm{a}$ \\
\hline TOTAL & 982 & 100 & 442 & 100 & 100 \\
\hline
\end{tabular}

*PETER FRONCZEK \& PATRICIA JOHNSON, U.S. DEP'T OF COMMERCE, OCCUPATIONS 2000 1-2, 8 (2003), available at http://www.census.gov/prod/2003pubs/c2kbr-25.pdf. Because the census figures include only those employed outside the home, these percentages do not include homemakers or other non-compensated occupations.

commission members were drawn from the ranks of PTM occupations..$^{70}$ Our two previous surveys, focusing on Iowa and Oregon, also identified a very similar skew toward white-collar members.

The Iowa/Oregon surveys also found that, as city size increases, the percentage of board members in the PTM class increases. In the Iowa survey, for example, the smallest towns (less than 2500 population) had only $41 \%$ PTM members on their P\&Z commissions, increasing steadily as population increased to $74 \%$ for cities over $25,000 .{ }^{71}$ Similarly, in Oregon the smaller towns had 68\% PTM members, increasing to over $90 \%$ in cities over $25,000 .{ }^{72}$ In the nationwide survey, however, the relationship between city size and proportion of white-collar board members was not well-defined, as Table 3 shows. Certainly, the largest cities had P\&Z commissions made up almost entirely of those with PTM occupations. For mid-size and smaller cities, however, there was no identifiable trend. Of course, all the cities in the national survey would have been in the largest category of the Iowa/Oregon studies.

While the data showing a skew toward white-collar board members is interesting, it is not the complete story. The PTM category, for example,

70. See Anderson \& Sass, supra note 7, at 458.

71. See Anderson \& Sass, supra note 7, at 464.

72. See Anderson \& Luebbering, supra note 59, at 72. 
Table 3: Percentage of PTM Board Members by City Size

\begin{tabular}{lcc}
\hline City size & P\&Z & BZA \\
\hline above 500,000 & 94 & $\mathrm{n} / \mathrm{a}^{*}$ \\
250,000 to 500,000 & 73 & 77 \\
100,000 to 250,000 & 79 & 70 \\
under 100,000 & 77 & 80 \\
\hline
\end{tabular}

*We did not obtain BZA data for the largest cities in the survey.

is a large classification that includes everyone from attorneys to engineers to small business owners. To fully discover who is sitting on our zoning boards, we looked at the specific occupations within these groups. Table 4 shows the total number and percentage of board members by specific occupation.

The top four occupations on both boards-business, real estate, politics, and law-account for $57 \%$ of $P \& Z$ commission members and $68 \%$ of BZA members. Those in the real estate category represent a significant portion by themselves (18\% P\&Z; 22\% BZA). If that group is added to others which are related to the development process, such as bankers (mortgages), planners, and architects-over 30\% of board members have some vested interest in development. Of course, many of the attorneys and engineers may also work in real estate development as well.

On the other hand, some balance is reflected in the presence of a significant group of educators. Some of these, particularly in larger cities, were professors of urban planning or something similar, who would bring an expertise and broader perspective to the board. In addition, many of the boards achieved balance by including public housing or charitable group officials, who were represented in about the same proportion as bankers or planners.

However, it is easy to see what occupations are not at the table. Only $1-2 \%$ of the members are laborers, meaning that the blue-collar worker has virtually no voice in this process, although in some cities political representatives from blue-collar districts may indirectly represent those interests. Even though a fair number of members were classified in "clerical/sales" occupations, for the most part they were either real estate agents, insurance brokers, or paralegals, who may have some direct or indirect interest in development. Thus, as Robert Walker suggested, the view of the "ordinary citizen" is not represented with this occupational composition. 
Table 4: Board Members by Specific Occupation

\begin{tabular}{|c|c|c|c|c|}
\hline \multirow[b]{2}{*}{ Occupation } & \multicolumn{2}{|c|}{ P\&Z Commission } & \multicolumn{2}{|c|}{ BOA } \\
\hline & Number & Percent & Number & Percent \\
\hline Business & 177 & 18 & 104 & 24 \\
\hline $\begin{array}{l}\text { Real estate } \\
\text { development } \\
\text { (construction, } \\
\text { sales, appraisal) }\end{array}$ & 177 & 18 & 95 & 22 \\
\hline $\begin{array}{l}\text { Politics, } \\
\text { government }\end{array}$ & 108 & 11 & 37 & 8 \\
\hline $\begin{array}{l}\text { Attorney, } \\
\text { paralegal }\end{array}$ & 100 & 10 & 60 & 14 \\
\hline Education & 63 & 6 & 23 & 5 \\
\hline $\begin{array}{l}\text { Architect, } \\
\text { landscape arch. }\end{array}$ & 61 & 6 & 25 & 6 \\
\hline Engineering & 52 & 5 & 20 & 5 \\
\hline Banking & 34 & 3 & 9 & 2 \\
\hline $\begin{array}{l}\text { Insurance, financial } \\
\text { planning }\end{array}$ & 29 & 3 & 13 & 3 \\
\hline Planning & 28 & 3 & 4 & 1 \\
\hline $\begin{array}{l}\text { Charity, social } \\
\text { work }\end{array}$ & 27 & 3 & 7 & 2 \\
\hline Medical & 27 & 3 & 7 & 2 \\
\hline Homemaker & 26 & 3 & 7 & 2 \\
\hline Science, technology & 20 & 2 & 3 & 1 \\
\hline $\begin{array}{l}\text { Community devel., } \\
\text { public housing }\end{array}$ & 18 & 2 & 4 & 1 \\
\hline $\begin{array}{l}\text { Artist, writer, } \\
\text { editor }\end{array}$ & 11 & 1 & 3 & 1 \\
\hline Military & 10 & 1 & 5 & 1 \\
\hline Labor & 5 & 1 & 7 & 2 \\
\hline Religion & 5 & 1 & 3 & 1 \\
\hline Agriculture* & 1 & 0 & 1 & 0 \\
\hline Other, retired & 3 & 0 & 4 & 1 \\
\hline TOTAL & 982 & 100 & 441 & 100 \\
\hline
\end{tabular}

*Table 2 shows five P\&Z members in the agricultural group; however, two of those members were only part-time farmers and for this table were placed in another category. Another member was an irrigation contractor, which is an agricultural classification for Table 2, but here falls under the real estate development group. 
The board composition totals may reflect a philosophy of treating zoning boards as economic development tools. City officials may perceive that facilitating "growth" is the main object of city planning. ${ }^{73}$ Of course, many planning or zoning board members obtain their seats precisely because they represent a group with a vested interest in the planning process. Rather than attempt to identify "neutral" citizens, a city may instead try to strike a balance between various competing interests.

New York City's Planning Commission perfectly illustrates the composition issue. The Commission, when surveyed in 2007, consisted of thirteen board members. Every single Commission member was drawn from the professional, managerial, technical class and every single member had at least an indirect and in many cases a direct interest in development activity. The Commission included three architects, two attorneys, five executives from housing or community development organizations, one real estate broker, one executive of a construction company, and one engineer. Granted, several of the development executives worked in the affordable or low-income housing area. Nevertheless, every single member had some sort of vested interest in the development process and none could be said to represent the point of view of the "average citizen."

\section{Conclusion}

Judicial deference to zoning board decisions is based on the assumption that they are neutral administrative bodies representing a fair crosssection of the community. ${ }^{74}$ The actual composition of these boards, however, cannot be fairly said to reflect the average citizen's point of view. Unless municipalities begin to appoint more representative boards, legitimate questions may be raised about the appropriateness of judicial deference.

\section{Survey of Public Attitudes Toward Land}

\section{Use Issues}

Given the skew toward white-collar occupations, we were interested in determining the extent to which demographic variables affected attitudes

73. Marion Clawson \& Peter Hall, Planning and Urban Growth: An ANGLO-AMERICAN COMPARISON 181 (1972) (describing the prevailing American attitude favoring growth and development).

74. See supra note 43 and accompanying text. 
toward zoning issues. For example, even though the labor group is almost totally excluded from board representation, would more blue-collar presence actually make a difference in the decision-making process? We therefore devised a survey to test attitudes toward land use questions and analyzed the results by a number of demographic characteristics.

\section{A. Study Design}

During the summer of 2007, Drake researchers surveyed Iowa residents regarding their attitudes toward specific land use control issues. The survey was conducted at various public locations, to ensure a diverse set of respondents. The locations included sporting events, city parks, and ethnic festivals in central Iowa. The survey respondents were volunteers and were typically compensated for their time with nominal gifts, such as a bottle of water or a $\$ 5$ gift certificate. The researchers attempted to ensure that the results included a significant number of respondents in all demographic categories. We received a total of 801 usable responses. About $42 \%$ of the respondents held occupations in the professional, managerial, and technical category, slightly above their share of the nation's workforce (34\%), while the rest were distributed among the non-professional occupations.

\section{B. Survey Summary}

The survey instrument asks the subject to assume that they are a member of the city's planning and zoning commission. The basic role of the planning and zoning commission is explained briefly. The subject then is asked a series of questions about issues that may come before the commission. For each question, the subject has a choice of five responses: Definitely Yes, Probably Yes, Unsure, Probably No, and Definitely No.

Table 5: Occupations of Survey Respondents

\begin{tabular}{lc}
\hline Occupational Group & Percent of Respondents \\
\hline Prof., Tech., Managerial & 42 \\
Service & 21 \\
Labor & 12 \\
Sales/Clerical & 6 \\
Homemaker & 5 \\
Agriculture & 2 \\
Unemployed/student & 11 \\
\hline
\end{tabular}


The subject is then asked to provide demographic information regarding his or her occupation, educational level, annual family income, race, age, and home ownership. The complete survey instrument is included in this article as Appendix 1.

The survey focuses on controversial issues on which Robert Walker's "ordinary citizen" might be expected to take a different position than the white-collar professional, particularly one with ties to business or development interests. Thus, the survey asks whether a big box store should be granted a zoning amendment, despite the adverse impacts of the project on a moderate-income neighborhood. Another question focuses on whether a gated community should be required to allow public access. Other questions concern development exactions, historic preservation, and sustainable development. The survey questions are summarized below, along with the background of each issue.

QUESTIONS 1-3: THE BIG BOX STORE VS.

NEIGHBORHOOD CONCERNS

The survey's first three questions concerned a proposal to build a bigbox store on land presently zoned agricultural, located adjacent to a modest residential area, consisting of small houses on small lots. The development would require a zoning change from agricultural to commercial. The change is supported by city leaders, eager for additional development, but opposed by neighbors, who are concerned about additional noise, traffic, and loss of privacy.

Question 1 asks whether the subject would vote to recommend the zoning change in these circumstances. Question 2 asks whether the subject would require the developer to screen the site with bushes or a fence, at a cost of $\$ 75,000$, to reduce the impact on neighbors. The developer claims that this expense might render the project infeasible. Question 3 asks whether the subject would allow the developer to straighten a stream running through the site, turning it into a concrete culvert. The developer claims that if the stream is left in its natural, meandering, location, the smaller buildable area will render the project unworkable.

These questions were designed to determine how much value the subject placed on economic development as opposed to neighborhood and environmental concerns. Zoning amendments to allow big box retail are quite common, ${ }^{75}$ but can generate significant neighborhood

75. For a summary of empirical research on frequency of zoning amendments, see Ellickson \& Been, supra note 6, at 346-47. 
opposition due to increased traffic, noise, and other impacts ${ }^{76}$ Because the neighborhood was depicted as modest, our hypothesis was that the "ordinary citizen" imagined by Robert Walker might be more protective of the surrounding neighborhood, compared with those who normally sit on zoning boards. ${ }^{77}$

\section{QUESTION 4: EXACTIONS}

Question 4 asks whether the subject favors a requirement that every new residential development be required to provide a portion of the development for public recreational needs. Exactions for public park and recreation uses are strongly opposed by many developers, builders and business leaders seeking economic growth. ${ }^{78}$ The National Association of Home Builders, for example, states as a matter of policy that the cost of improvements designed to serve the entire community, such as parks, should be financed by taxes rather than by exactions on new development. ${ }^{79}$ Municipalities, however, have increasingly relied on exactions to provide public amenities. ${ }^{80}$

From a legal standpoint, such exactions are permissible provided that the municipality has adequate statutory authority ${ }^{81}$ and stays within constitutional bounds. In Nollan v. California Coastal Comm' $n^{82}$ and Dolan v. City of Tigard, ${ }^{83}$ the Supreme Court held that the Constitution allows exactions only where an adequate nexus exists between the requirement and the projected impact of the development ${ }^{84}$ In addition, the exaction must bear a "rough proportionality" to the nature and extent of the added burden on public services posed by the new development. ${ }^{85}$

76. See, e.g., Stacy Mitchell, Big Box Swindle: The Fight to Reclaim America from Retail Giants, http://www.alternet.org/story/45166/ (last vistited Sept. 20, 2008) (describing opposition to big box retail proposals in several communities).

77. See Allensworth, supra note 17, at 80-81 (describing study that determined zoning board members representing citizen groups voted against rezonings at "significantly greater rate than those supported by developers).

78. Marla Dresch \& Steven M. Scheffrin, Who Pays for Development Fees AND ExaCtions?, http://www.ppic.org (last visited Apr. 1, 2008) (stating that business groups claim exactions impede economic growth).

79. See National Association of Home Builders, http://www.nahb.org/generic.aspx? sectionID=893\&genericContentID=3518 (last visited Apr. 1, 2008).

80. MANDELKER, supra note 19, at 398.

81. Home Builders Ass'n of Greater Des Moines v. City of West Des Moines, 644 N.W.2d 339, 350 (Iowa 2002) (stating that a city parkland dedication ordinance was tax not authorized by state statute).

82. 483 U.S. 825 (1987).

83. Dolan v. City of Tigard, 512 U.S. 374 (1994).

84. Id. at 386 .

85. Id. at 391 . 
Park and recreation exactions such as the one proposed here have been upheld under the Nollan/Dolan constitutional test. ${ }^{86}$

This question is designed to see whether the "ordinary citizen" might be more willing to favor burdens on developers that benefit the community, even if it might impede growth.

\section{QUESTION 5: GATED COMMUNITY ACCESS}

Question 5 presents a hypothetical proposal for a gated community, which would present an inconvenient barrier to public access to a hiking/ biking trail, and asks whether the subject favors requiring the gated community to allow public access to the development's streets and sidewalks.

Gated communities, already home to millions of Americans, are the fastest-growing form of residential development. ${ }^{87}$ Motivated primarily by the desire for increased security, these areas privatize space that was previously public, preventing access by non-residents. ${ }^{88}$ At least one scholar has argued that this may, in some cases, impermissibly infringe on the constitutional right to travel. ${ }^{89}$ Some communities have restricted or even banned gated developments due to their adverse effects on the public. ${ }^{90}$

Among the unintended consequences of the gated development are a sense of exclusion and social segregation..$^{91}$ The consequences of the privatization of space should be considered immediately apparent and widely significant to sociological study. Public spaces are centers of integration where individuals of widely divergent social factors-age, race, ethnicity, income, etc.-work, live, and recreate in close proximity. Public space contributes to egalitarianism and liberalism by fostering unplanned social interactions between individuals who would not otherwise associate with one another. However, studies into housing

86. Twin Lakes Dev. Corp. v. Town of Monroe, 801 N.E.2d 821 (N.Y. 2003) (upholding \$1500 per lot parkland fee ordinance).

87. Setha M. Low, Imprisoned by the Walls Built to Keep 'the Others' Out, L.A. Times, Dec. 19, 2003, available at http://www.hba.org.my/news/2003/1203/impris oned.htm. In 2001, 7 million U.S. homes were located in gated environments. Id.

88. See generally Edward J. Blakely \& Mary Gail Snyder, Fortress America: Gated Communities in the United States 126 (Brookings Institute Press 1997) (stating that $70 \%$ of residents said security was very important in their decision to live in a gated community).

89. David J. Kennedy, Residential Associations as State Actors: Regulating the Impact of Gated Communities on Nonmembers, 105 Yale L. J. 761, 769-70 (1995).

90. Blakely \& Snyder, supra note 88, at 156-60.

91. Id. 
trends showed that an increasing number of city dwellers seek to escape the modern urban landscape in favor of communities comprised of individuals whose social characteristics match their own. As a result, private spaces become acutely homogenized places, contributing to the spatial stratification of the urban landscape..$^{92}$

Many social scientists lament that every new gated community detracts from the overall public space available. "As public spaces are lost, so too are the opportunities for shared experience and positive interaction among individuals from diverse backgrounds." ${ }^{\prime 93}$

Historically, gated communities have been seen as mostly white professional enclaves, contributing to social segregation by race and class. ${ }^{94}$ Thus, this question was designed to determine whether the groups typically excluded-minorities, blue-collar workers, or those with lower incomes-would be more likely to impose access requirements. Recent studies suggest, however, that gated communities are becoming more popular with the middle class and a variety of ethnic and racial groups..$^{95}$

\section{QUESTION 6: SUSTAINABLE DEVELOPMENT}

Question 6 asks whether the subject favors requiring developers to use more sustainable building practices, even if it increases the cost of the development by $10 \%$. Recent years have seen an explosion of "green building" codes, as cities and counties attempt to reverse decades of conventional subdivision controls that exacerbate environmental problems. ${ }^{96}$ For example, instead of drainage systems that channel stormwater runoff into curb and gutter systems, which adversely impact water quality, low impact development strategies may include on-site retention of stormwater using native vegetation or increased use of permeable

92. Elena Vesselinov, Matthew Cazessus \& William Falk, Gated Communities and Spatial Inequality, 29 J. UrB. AfF. 109, 111 (2007).

93. Id.

94. Setha M. Low, The Edge and the Center: Gated Communities and the Discourse of Urban Fear, 103 AM. ANTHROPOLOGIST 45 (2001) (stating that the gated community "produces a landscape that encodes class relations and residential (race/class/ethnic/ gender) segregation more permanently in the built environment").

95. Vesselinov, supra note 92, at 113. The 2001 American Housing Survey of the U.S. South and West shows that Asians and Hispanics have the highest percentages of their overall populations living in gated communities (12.4\% and $8.3 \%$ respectively), while $7.2 \%$ of white and $3.5 \%$ of black homeowners are gated. Id. at 115 .

96. See Smart Communities Network, http://www.smartcommunities.ncat.org/build ings/gbcodtoc.shtml (last visited Apr. 1, 2008). 
pavement. ${ }^{97}$ Developers, however, may believe that these practices are too costly or restrictive. ${ }^{98}$

This question was designed to see whether changing the demographic characteristics of zoning boards would hasten or impede the trend towards sustainable development requirements.

\section{QUESTIONS 7-8: HISTORIC PRESERVATION}

Questions 7 and 8 deal with historic preservation in an area described as replete with residential and commercial buildings "built in the 1920s in a particularly attractive architectural style." A developer plans to take down several of the buildings in order to construct a modern office building. Question 7 asks whether the subject favors historic preservation restrictions in these circumstances. Question 8 asks whether the subject would favor historic preservation restrictions if property owners are compensated by tax reductions or incentives.

Historic preservation is largely a matter of local law. Federal law provides designated historic buildings or districts with grant funding opportunities and tax incentives and offers some protection from detrimental federal projects. ${ }^{99}$ Restrictions on the destruction or modification of historic property, however, are found primarily at the local level. ${ }^{100}$ Local preservation ordinances became very popular in the latter part of the 20th century. In 1975, 421 communities had preservation controls; by 2002 , over 2300 communities had them. ${ }^{101}$

The enactment of an historic preservation ordinance can be extremely controversial. ${ }^{102}$ Ordinances typically impose significant restrictions on

97. For examples of ordinances requiring or encouraging this type of low impact design, see Marisa Romero \& Mark E. Hostetler, Policies That Address Sustainable Site Development, http://edis.ifas.ufl.edu/UW254 (last visited Apr. 1, 2008).

98. However, many builders now support the green building movement, citing costefficiency and marketability. See Michael Hinman, Panel: Green Building Movement Here to Stay, More Cost Efficient, TAmPa BAy Bus. J., Nov. 13, 2007, available at http://www.bizjournals.com/tampabay/stories/2007/11/12/daily16.html.

99. National Historic Preservation Act of 1966, 16 U.S.C. $\$ 470$ (2008).

100. There are some state-level statutory protections against the destruction of historic properties, see, e.g., TenN. CodE ANN. §§ 7-51-1201 to -1204 (2008), but most state statutes merely authorize local governments to enact protection ordinances. See, e.g., Colo. Rev. Stat. § 29-20-104, Ga. Code AnN. §§ 44-10-20 to -31 (2007).

101. See Tad Heuer, Note, Living History: How Homeowners in a New Local Historic District Negotiate Their Legal Obligations, 116 YALE L.J. 768, 772-73 (2007).

102. See, e.g., Carole Townsend, Preservation Confrontation: Norcross Removes Historic Property Protection Ordinance for the Second Time in 20 Years, GwInnetT DAILY Post, Feb. 24, 2008, available at http://www.gwinnettdailypost.com. City council enacted historic preservation ordinance, but soon retracted it when some property owners complained. Id. 
property owners and may increase the cost of maintaining the property. ${ }^{103}$ However, owners living in a historic district may feel that the additional burden is worth the benefit of similar restrictions on neighboring properties ${ }^{104}$ Clearly, the public at large is benefitted by the restrictions, which can effectively turn neighborhoods into outdoor museums.

\section{Overall Survey Results}

Table 5 shows the total affirmative and negative responses in each category. The results group together the "probably" and "definitely" responses for simplicity. The table shows the percentage of total respondents who answered affirmatively. The next column subtracts the "unsure" responses and shows the percentage of those with an opinion who answered affirmatively. Finally, in order to determine the "average" response, we assigned each response a numerical value. "Definitely yes" was scored as +2 , "probably yes" was scored as +1 , "unsure" was scored as 0 , "probably no" was scored as -1 , and "definitely no" was scored as -2 . For each question, those scores were then totaled and averaged to determine the average response. Thus, 2.0 would be the highest possible affirmative score, -2.0 would be the highest negative score, while a score near 0 would indicate that the average respondent was neutral on the issue. A score around 1.0 indicates that the average respondent was leaning toward the proposition-a "probably yes" response.

The results show the average citizen may be less interested in economic development and more concerned about urban sprawl or the impacts of commercial enterprises on residential neighborhoods. With regard to big box rezoning, for example, only about half of the respondents would grant the application. The average response was .06, which is almost exactly neutral. Yet, this is a typical zoning amendment granted in cities across the country every day and is especially favored in areas desiring "economic growth." 105 Moreover, if the development proceeds, about three-quarters of respondents likely would require a screen to protect nearby residents and $70 \%$ would require the stream to be left intact, despite the developer's difficulties. The average response to these questions was .85 and .83 , respectively, which is well into the

103. See Heuer, supra note 101, at 799-800 (describing owners' difficulties complying with historic preservation controls).

104. Id. at 786-87 (describing an empirical study of owners in a historic district that finds the majority felt advantages outweighed the disadvantages).

105. For a description of the typical city approach to "deal-making" with development interests and a summary of empirical studies on zoning amendments, see Ellickson \& Been, supra note 6, at 342-47. 
Table 6: Overall Survey Results

\begin{tabular}{lccc}
\hline Question & $\begin{array}{c}\text { Affirmative Percent } \\
\text { of Total Responses }\end{array}$ & $\begin{array}{c}\text { Affirmative } \\
\text { Percent of Those } \\
\text { With Opinion }\end{array}$ & $\begin{array}{c}\text { Average } \\
\text { Response }\end{array}$ \\
\hline Q1: Big Box Rezoning & 46 & 54 & .06 \\
Q2: Screen Require & 74 & 83 & .85 \\
Q3: Stream Preserve & 70 & 79 & .83 \\
Q4: Rec Exaction & 76 & 86 & .94 \\
Q5: Gated Access & 66 & 74 & .68 \\
Q6: Sustain Develop & 69 & 86 & .79 \\
Q7: Historic Pres. & 63 & 79 & .65 \\
Q8: Hist. Pres. w/taxes & 65 & 85 & .69 \\
\hline
\end{tabular}

"probably yes" category. Again, this seems to illustrate that the average citizen has significant concerns about development impacts on the environment and the neighborhood.

Similarly, despite the controversial nature of recreational exactions, $86 \%$ of those with an opinion favored requiring new developments to contribute toward public park and recreation facilities. This question generated the highest average response (.94). On the question of gated access, about two-thirds of all respondents and three-quarters of those with an opinion would require public access. While the affirmative response to this question was slightly lower than the answers to the development exaction and screen/stream conditions questions, this is a significant result given that the ability to prevent public access is the signal characteristic of a gated community and one that is rarely compromised by zoning boards. ${ }^{106}$ Again, these results indicate that the average citizen may have a different opinion than a typical zoning board member.

In addition, a healthy majority favored measures to require sustainable development techniques and historic preservation, despite the fact

106. See, e.g., Howard Blume, La Habra Shuts the Gates, L.A. Times, Sept. 20, 1990 at J7 (describing the city's ban on gated communities as extremely rare, if not unprecedented); see also Kanai Mayor Slams Gated Communities, Honolulu Star BulleTIN, (Feb. 10, 2008), available at http://starbulletin.com/2008/02/10/news/story07.html (describing recent effort to ban gated communities in Kauai). University of Hawai'i law professor David Callies criticized the plan on the basis that the constitution allows private landowners to exclude the public. Id. 
that neither is required in the communities in which the survey was taken. Again, this suggests that the overall community is more willing to regulate land use and development than a typical zoning board might be. The historic preservation questions, however, did not generate as strong of an affirmative response as the questions on recreational exactions and neighborhood and stream protection.

Overall, these results portray citizens who may not care as much about "growth" or "economic development" as they do about ensuring that growth is done the right way-with due regard for neighbors, natural amenities, sustainable development, public recreational needs, and historic preservation. The results suggest that a board composed of a broader cross section of citizens might make different decisions than a typical zoning board. The next section attempts to determine whether these opinions vary according to demographic characteristics.

\section{Survey Results by Demographic Variables}

Each survey respondent was asked to provide demographic data: age, educational level, income, home ownership, race, and occupation. Our hypothesis was that many of these factors would correlate with significant differences in opinion on zoning matters. The object was to determine whether having more diverse zoning boards might lead to better representation of competing concerns.

For many demographic variables, the survey did not reveal many significant differences between categories. This suggests that, at least for broad demographic categories, planning and zoning decisions would not be appreciably affected by greater diversity of board members. However, a closer analysis reveals that certain factors do result in differences in zoning preferences. Those differences discussed below rise to the level of statistical significance, unless we specifically indicate otherwise. ${ }^{107}$

For each demographic variable, the first table summarizes the total percentage of affirmative responses to each question. "Definitely yes" and "probably yes" responses were combined for these tables in order to obtain the total number of affirmative answers. For these percentage tables, the uncertain responses were disregarded, meaning that these are percentages of those who had an opinion. The second table in each category shows the average response of each group to each

107. Statistical significance exists when a difference between samples/responses is large enough so as to be attributed to something other than expected sampling error. 
question. ${ }^{108}$ The following sections detail the responses for each demographic variable.

\section{OCCUPATION}

This survey was intended to determine whether increasing diversity of occupations on zoning boards would impact the decision-making process. As a group, the responses of non-professionals were almost identical to the responses of professionals on every issue. ${ }^{109}$ Non-professional respondents were only slightly less likely to recommend the big box rezoning than the white-collar group (53\% to 56\%, no statistical significance). Similarly, the two groups were almost equally likely to require screening (84\% and $83 \%$ ). The professional group was slightly more likely to leave the stream intact (82\% versus $78 \%$ ) and slightly less likely to require gated community access $(71 \%$ versus $76 \%)$, but the differences were not statistically significant. On the remaining questions, the responses were virtually indistinguishable.

However, when the non-professional group is broken down into subgroups, there are some significant differences. For example, with respect to big box rezoning, those identified as retired, sales/clerical, or homemakers were much less likely (45\%) than the professional and service group (57\%) to recommend the rezoning. The average respondent (Chart 1) in the labor, service, homemaker, and sales groups was about neutral on the big box rezoning issue, while the average professional leaned towards granting the application $(+.47)$. The average agricultural respondent leaned heavily against the rezoning. These results seem to indicate that professional respondents value economic development, while the other groups place more value on neighborhood concerns.

Moreover, if the big box rezoning were granted, the sales/clerical and agricultural groups were more likely to impose the screening (Chart 2) and stream preservation (Chart 3) requirements than the professional group. Conversely, the labor group was less concerned about screening for the neighbors or stream preservation than any other group. Interestingly, our hypothesis was that blue-collar workers, especially those in the labor group, would be more likely to require screening to protect the modest neighborhood adjacent to the big box store. That is apparently not the case.

108. In some cases the category groupings do not match for the two tables because it was necessary to combine subgroups to achieve statistical significance.

109. See Chart 5 infra. 


\section{Chart 1: Big Box Rezoning Average Response by Occupation}

\begin{tabular}{|l|}
\hline 0.80 \\
\hline-0.40 \\
-0.60 \\
-0.80 \\
\hline Professional \\
\hline Service
\end{tabular}

With respect to the gated community, three of the non-professional groups (labor, homemaker, and service) were more likely to demand access than the professional group, while the sales/clerical and agricultural groups were less likely, as shown in Chart 4. This does seem to indicate that those groups typically excluded from gated communities, where they exist as mostly professional enclaves, are less likely to allow this exclusion. Finally, the professional group was significantly more interested in tax breaks for historic preservation (88\%) than the labor or service group (78\%).

Farmers presented the most salient differences with the other occupational categories. For example, farmers were far more protective than the other groups of the agricultural land involved in the rezoning question. Only $25 \%$ of the agricultural group would grant the rezoning, compared to $56 \%$ of the professionals and $58 \%$ of the service group. The average response of the agricultural group to the rezoning question was firmly negative ( -.67$)$, while the professional group was about as strong $(+.47)$ in the opposite direction. Moreover, were the 


\section{Chart 2: Screen-Average Response by Occupation}

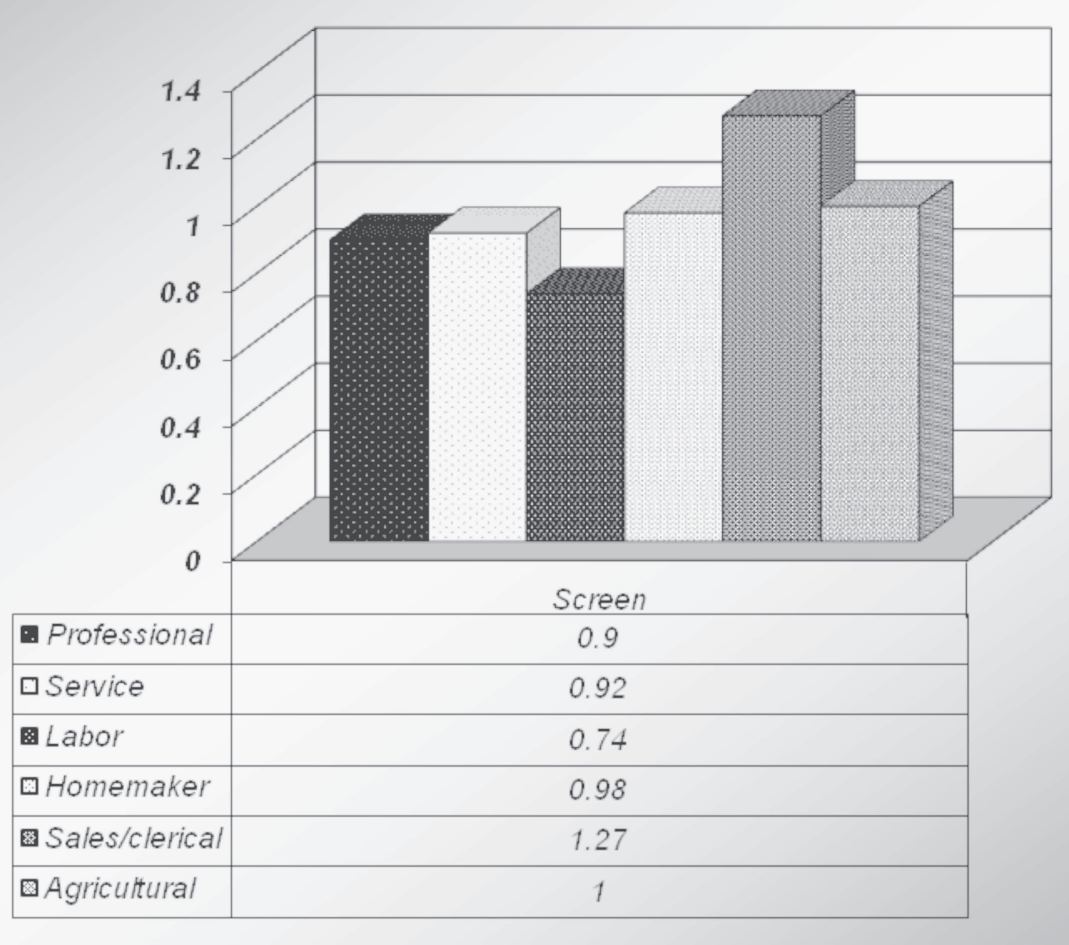

rezoning to be granted, $93 \%$ of the agricultural group would demand screening and $92 \%$ would require the stream to be left intact, indicating a strong preference for control of commercial development and respect for nature. The agricultural group was also the most interested in requiring sustainable development and historic preservation. It may be that farmers, who have long had to use conservation techniques and deal with government regulation of their farming methods, are more likely to require sauce for the gander as well. Finally, the farmers were least interested in gated community access, perhaps placing more value on the right to exclude. Ironically, while the results indicate that the agricultural group has the most distinct set of opinions, and may present the strongest voice against urban sprawl, they are almost entirely excluded from the municipal planning and zoning process.

We attempted to identify those respondents whose occupations could be classified as "development-related," to determine whether their responses differed from the remainder of the group. Only 21 respondents 


\section{Chart 3: Stream-Average Response by Occupation}

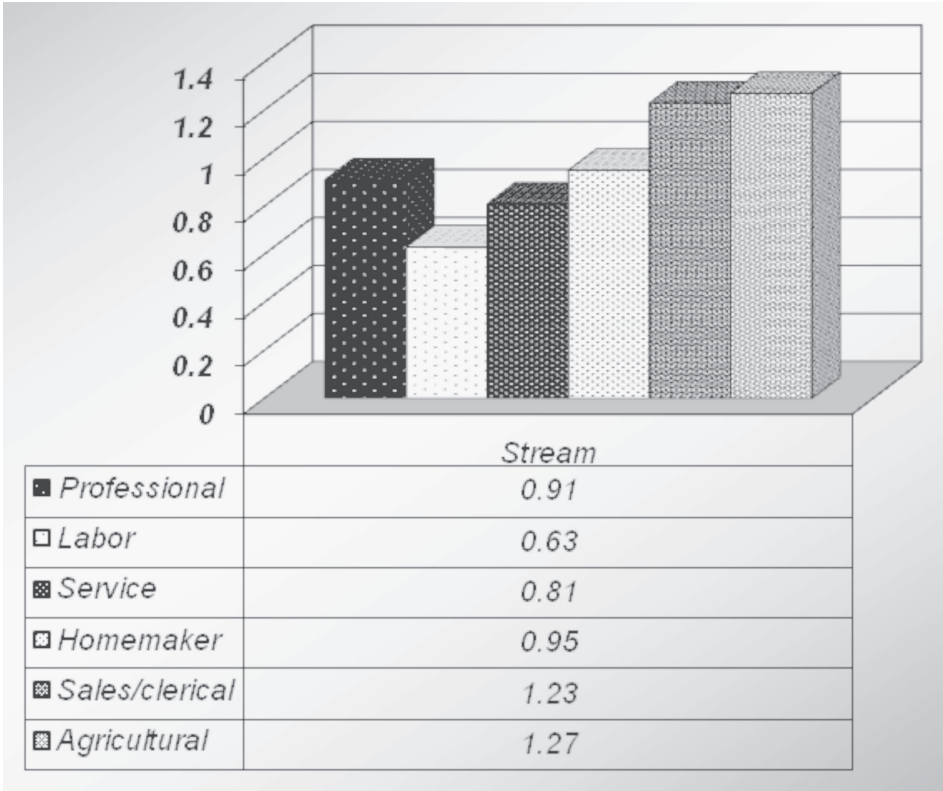

were clearly in this category, including occupations such as real estate agents, builders, landscapers, and architects. Contrary to our expectations, this group did not favor the developer. In fact, the development group was among the least likely to approve the big box rezoning. Moreover, this group was very favorably inclined toward the screening and stream requirements, sustainable development, historic preservation, and even gated community access. Certainly, the small sample size and the possibility of sample bias ${ }^{110}$ cautions against reading too much into these results. On the other hand, the results indicate that even with a board made up entirely of individuals with development-related occupations, opinions on zoning issues may be remarkably diverse. ${ }^{111}$

110. We collected a significant portion of the survey responses at a Des Moines park, so respondents may have been more favorably inclined toward environmental/recreational interests than the general public.

111. For example, on the issue of whether to grant the big box rezoning, the four voting "definitely yes" included a real estate agent, mobile home salesperson, construction worker, and a roofer, while those voting "definitely no" included a builder, three people involved in construction, and one in commercial real estate sales. 
Chart 4: Gated Access Percentage Preference by Occupation

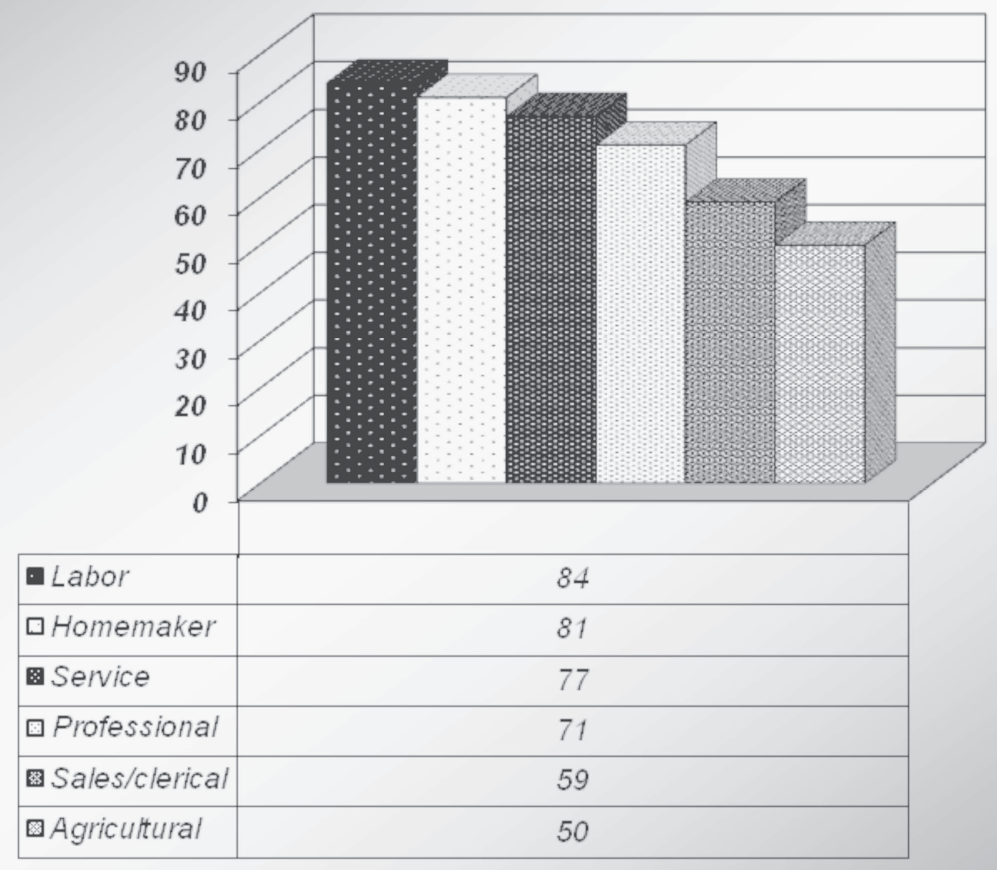

Chart 5: Comparison of PTM and DevelopmentRelated Responses

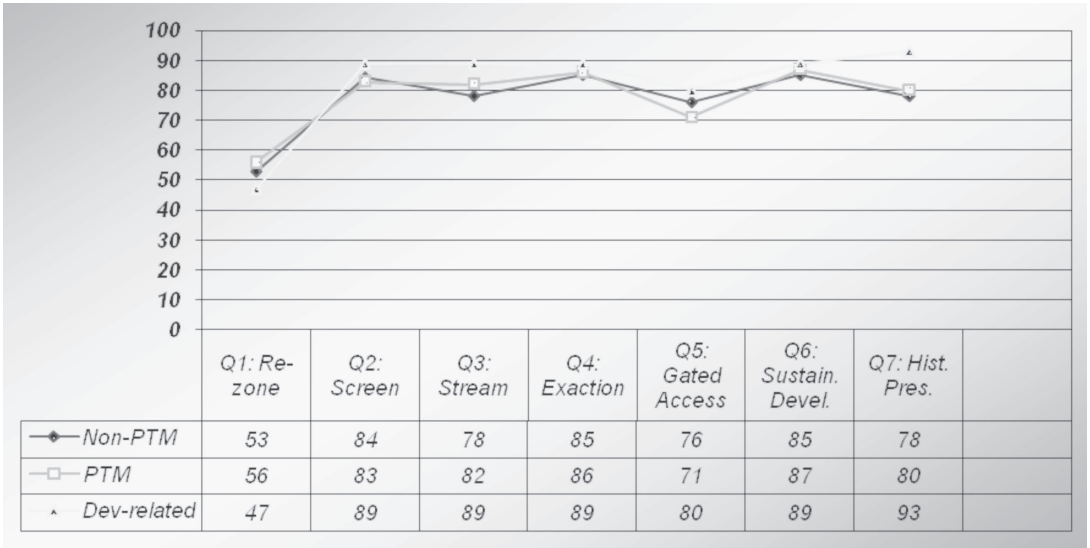


2. AGE

Differences in responses based on age categories do not, for the most part, rise to the level of statistical significance. In response to the initial question of whether to recommend the rezoning, while a slightly greater percentage of the young (56\%) and old (54\%) groups would allow the store than the middle-aged group (52\%), these differences are not statistically significant. The average responses indicate that the oldest group (65 and over) is more concerned about the neighbors (screening) than the natural environment (stream), while the other groups from 25-64 feel more strongly about the stream than the neighbors. The oldest citizens also cared the least about gated community access, probably placing security concerns over public trail access.

The middle-aged group tended to be a bit harder on the developers than either the youngest or oldest group. For example, when combining the responses of ages $35-54,85 \%$ would require the big box store's stream to be left in its original condition. Of those younger than 35 , only $76 \%$ would require it, almost identical to the percentage in the oldest group, those over 55. In addition, the middle-aged group is slightly more likely (83\%) to favor historic preservation controls than the combined oldest and youngest groups (76\%). These are statistically significant variations, which may indicate that middle-aged citizens either place slightly more emphasis on environmental/historical concerns or have slightly less concern for developers. ${ }^{12}$ The average response results indicate that the very oldest citizens are much less likely to impose historic preservation controls, which seems slightly counter-intuitive.

\section{EDUCATION}

Some interesting variations can be found among those of different education levels. Generally speaking, the highest-educated group was least likely to allow the big box rezoning and most likely to favor sustainable development requirements and historic preservation controls. Only $49 \%$ of those with advanced degrees would vote in favor of the rezoning, while $55 \%$ of those with less education would do so; this difference is not statistically significant. It is statistically significant that $93 \%$ of the highest-educated group would favor historic preservation with tax

112. The middle-aged group roughly correlates with the baby boomer generation, which would have been 41-61 years old at the time of this survey. Baby boomers may expect more from government than those in other generations. See AARP, A Changing Political Landscape As One Generation Replaces Another 12 (2004), available at http://assets.aarp.org/rgcenter/general/boomer_politics.pdf. 
incentives, while only $76 \%$ of the least-educated group would do so. The average response table shows a progressively stronger interest in historic preservation as education increases. Similarly, $91 \%$ of the most highly educated group would require sustainable development, while only $84.5 \%$ of those with less education would do so. The average responses confirm that the more highly educated group was the most interested in these low-impact measures. The average responses to the recreational exaction question present a nice progression, with higher education correlating with more interest in requiring developers to provide trails and parks.

Higher education also correlated, albeit weakly, with more protection for the gated community. Eighty-one percent of those with no college education would require public access while only $72.6 \%$ of those with at least some college would do so. This is consistent with studies indicating that gated communities are typically populated by those with higher educational attainment. ${ }^{113}$ However, the average response to this question shows that those without high school diplomas feel about the same as those with advanced degrees on the question of access. The middle of the educational range, therefore-those with some college or with a bachelor's degree-are the ones least likely to require gated community access.

\section{INCOME}

Respondents at the lower end of the income scale were slightly more likely (57\%) to allow the big box store than those at the top end (51\%), but the difference was not statistically significant. The lower income group, however, was more likely to require screening to protect the moderate income housing adjacent to the store. Remarkably, 93\% of the lowest income group would require screening, and $88 \%$ of all those with incomes under $\$ 50,000$ would do so. At the high income end, however, only $79 \%$ of those earning over $\$ 75,000$ would require screening. Because the problem specified that the houses adjacent to the development were small, this could indicate that lower-income citizens would be more sensitive to impacts on modest neighborhoods. However, the average response table indicates that the very wealthiest segment also strongly supports the screening requirement. ${ }^{114}$

113. Vessilinov, supra note 92, at 116, fig. 3. Almost half of gated owners hold a college or graduate degree, compared with a third of non-gated owners. Id.

114. Perhaps the cost of the screen $(\$ 75,000)$ does not seem as significant to this group. 


\section{Chart 6: Percent Preference by Annual Income}

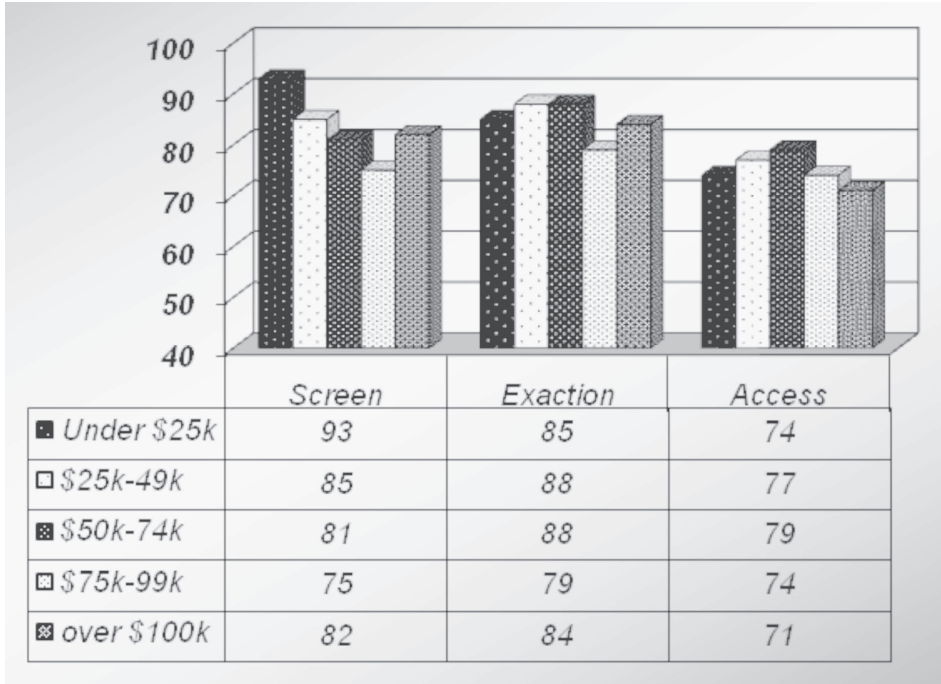

Lower income citizens were also slightly more likely to demand that developers donate bike trails and provide access to gated communities. About $88 \%$ of those earning below $\$ 75,000$ would require the recreational easements, while only $82 \%$ of those earning more than $\$ 75,000$ would. Similarly, $69 \%$ of those in the lower income categories would be likely to require gated community access, while only $61 \%$ of the upper income categories would. ${ }^{115}$ This is confirmed by the average response chart, which indicates that the top three levels of income category are much less interested in requiring gated community access than those in the lower income groups.

Conversely, the highest income group was significantly more likely to favor historic preservation restrictions (86\% to 77\%). That group also had the highest average response score on the historic preservation questions.

\section{TENURE}

Homeowners were slightly more likely to allow the big box rezoning than renters, but also would be more likely to require screens and stream preservation. The differences on these questions, however, were

115. These are percentages of all respondents, including those who were "uncertain." If "uncertain" responses are eliminated, there is still a marked difference between the groups (77\% for those under $\$ 75,000 /$ year compared to $72 \%$ for those over $\$ 75,000$ ), but it does not quite reach the level of statistical significance. 
not statistically significant. In fact, the average responses show that even though more homeowners leaned toward requiring screens, renters actually felt more strongly about requiring screens. There was virtually no difference between the groups' opinions regarding recreational easements.

As one might expect, a greater percentage of renters (78\%) than homeowners $(73 \%)$ wanted to require gated community access. While the difference was less than the statistical significance level, the average response table confirms this tendency, with renters scoring .2 above the homeowners on this question. Similarly, more homeowners favored historic preservation requirements, but again, just below significance. Finally, homeowners were more likely to require sustainable development (88\%) than non-homeowners (80\%), and the average score confirms this.

\section{RACE}

Generalizations about attitudes based on race are difficult due to the small number of non-white respondents. Of the 801 survey respondents, almost $84 \%$ were Caucasian, while only sixty-eight AfricanAmericans (9\%), forty-five Hispanic/Latinos (6\%), seventeen Asians (2\%), and seven Native Americans (1\%) were represented. Even these small numbers, however, indicate some significant attitude differences between racial groups.

Of all of the racial groups, African-Americans, Asians and Native Americans were least likely to grant the big box rezoning, while Hispanics were the most likely to recommend rezoning. The average response of the former three groups was in the negative range, while the average Hispanic response was +.31 . Caucasians were right in the middle of these groups. African-Americans were most likely to require screening to protect neighbors, while Asians were least likely. None of these differences, however, reached the level of statistical significance, due to the small sample sizes. The average response table indicates that Caucasians and African-Americans were almost equally likely to require stream preservation, screening, and recreational exactions.

The only statistically significant difference among racial groups was on the question of gated community access. Fairly low percentages of Native Americans (57\%), African-Americans (66\%) and Hispanics (69\%) would require access, while $100 \%$ of the small group of Asians surveyed would require access. Caucasians fell in the middle of these groups (76\%). The average response table confirms that Native Americans (.29) and African-Americans (.46) were the least likely to require access while Caucasians (.71) and Asians (1.35) would be much more likely to. 


\section{Chart 7: Zoning Preferences by Race}

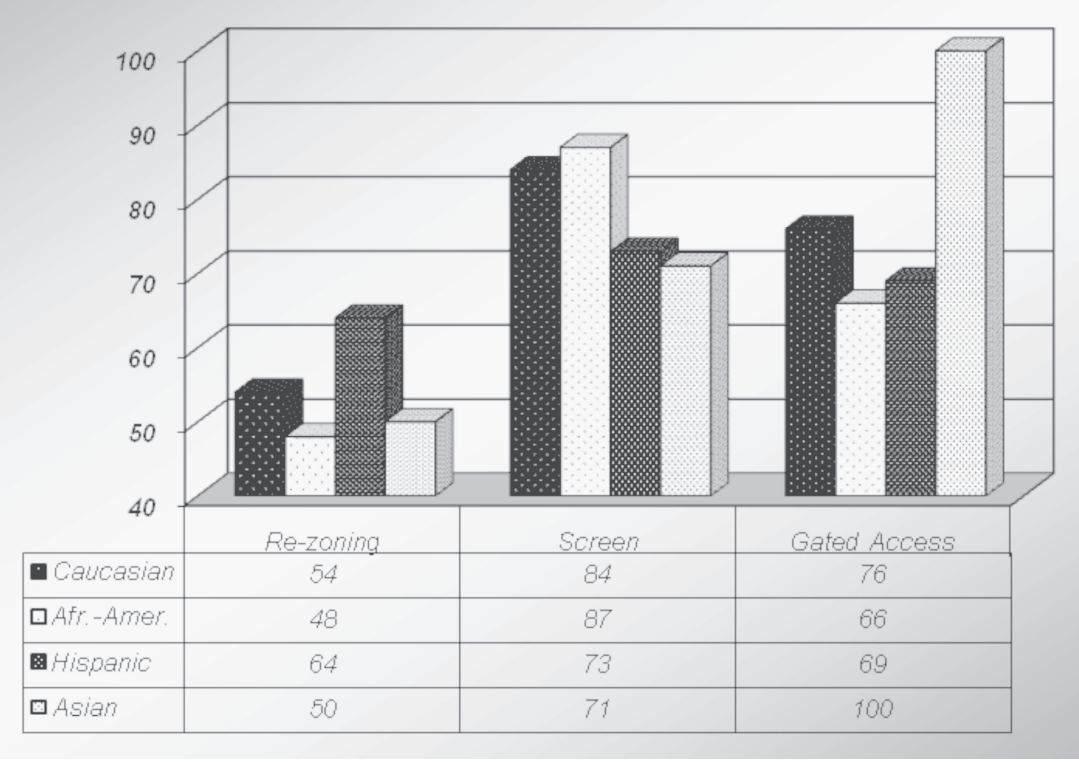

Interestingly, gated communities are seen by many as white enclaves, tending to exacerbate social segregation. ${ }^{116}$ Yet, the survey indicates that the racial groups historically shut out of these communities seem the least likely to demand access. While African-Americans have the lowest percentage of their population living in gated communities, the survey found that they were much less likely to require access than either whites or Asians, who have much higher percentages of gated community participants. At least some Asian countries have a tradition of public access to private land and it is possible that this traditional view of communal property could be reflected in some of those responses. ${ }^{117}$ Moreover, because one of the major motivations for moving to gated communities is fear of crime, ${ }^{118}$ it is possible that urban dwellers more readily relate to the desire for increased security.

116. See supra notes 87-95 and accompanying text.

117. See Jerry L. Anderson, Comparative Perspectives on Property Rights: The Right to Exclude, 56 J. LEGAL EDUC. 539, 544 (2006) (discussing communal hunting rights among Hmong in Laos).

118. See Low, supra note 94, at 55 (interviewing gated community members showed fear to be a major motivation). 


\section{E. Conclusions}

Perhaps the most significant results of this survey can be found in the overall responses to these zoning questions. The survey revealed that a large majority of the general public supports neighborhood protection and the public interest embodied in the environmental protection, historic preservation, and gated access proposals, despite the potential impact on economic development. Thus the survey seems to confirm that the "average citizen" may be more concerned with community impact than economic growth.

In addition, the survey confirmed our hypothesis that demographic variables could significantly affect these opinions, although not always in ways we would have predicted. Among the significant differences:

- Older citizens appear to care more about security and neighborhood protection than about recreation, historic preservation, or the environment.

- Those most likely to require screening to protect the moderate income neighborhood were those with lower incomes and less education. In addition to protecting moderate income housing, lower income citizens were more likely to demand public amenities and gated community access.

- Those most likely to require gated community access included Asian-Americans, renters, and those with lower incomes, while African-Americans, Hispanics, and those with higher education were least likely to require access.

- White-collar professionals were more likely to grant big box rezoning than any of the other groups. Those with labor occupations were less likely to require screening or stream preservation than any of the other employed groups. Laborers were also less interested in sustainable development and recreational exactions. Conversely, those with clerical/sales occupations were less likely to grant big box rezoning and were more protective of the neighborhood.

- Higher education correlated with stronger support for historic preservation, sustainable development requirements, and recreational exactions.

- Those with development-related occupations did not exhibit bias toward the developer; however, the sample size was too small to confirm this result.

In conclusion, it is difficult to generalize about exactly how zoning decisions might change if a broader array of occupations were represented on zoning boards. However, it is clear that various demographic 
characteristics correlate with differing attitudes toward zoning issues. The results do suggest that selecting a more representational group of citizens would ensure that a broader range of opinions on land use matters are brought to the table.

\section{Conclusion}

Individuals with white-collar occupations dominate zoning boards across the country. Moreover, certain types of professional occupations-business, real estate, law, bankers, planners, and architectsare disproportionately represented. In some cities, the majority of board members have some direct or indirect interest in the development process. The question, however, is whether this is necessarily a bad thing.

The perfect composition of a zoning board may depend on whether one views its assigned role in the process as "professional" or "political." Early in the history of comprehensive zoning, our relative inexperience with the concept of city planning may have required boards to be populated with "experts": architects who could analyze the impact of regulations on aesthetics, contractors who could assess the feasibility of design requirements and planners to provide the necessary urban design knowledge. ${ }^{119}$ Moreover, the boards may have needed civic and business leaders to ensure the legitimacy and public acceptance of relatively novel government controls. ${ }^{120}$ Boards populated by "experts" might have been trusted more than ordinary citizens to be fair and impartial. Now, however, the maturity of the planning process and the availability of expert planning staff may allow lay boards to draw on a broader constituency to fulfill a different role.

However, the ideal of a disinterested board member, "dedicated to the interest of the community as a whole"121 may be impossible to achieve. Observers have long recognized that the zoning process cannot be insulated from the political nature of land use decisions. In this view, there are no neutral participants; everyone has some stake in the

119. Frederick H. Bair, Jr., The Zoning Board Manual 110 (1984) (stating that historically, experts were needed on boards, but the role is now changing).

120. See Herbert J. Gans, People and Plans: Essays on Urban Problems and Solutions 59-63 (1968) (describing historic dominance of business and civic leaders on planning boards); Alan Altshuler, The City Planning Process 388-89 (1966) (stating that the value of the planning board depends on the stature of its members because of the need to cultivate support for plans).

121. BAIR, supra note 119 , at 110 (describing the ideal board member). 
process. Instead, the answer may lie in ensuring that the competing interest groups are adequately represented. ${ }^{122}$

If there is a conclusion to be drawn, it is that the citizen's board is, like just about everybody else with a role in the zoning process, probably going to suffer with—but nevertheless survive - a continuing st[r]eam of criticism from various forces and sources that question the legitimacy of its role. The temptations to join again the chorus of those deploring that situation must be tempered by the reality that such bodies, despite continuing professional criticism, survive and prosper and, when threatened, are jealously defended by most of the nonprofessional participants in the zoning process. One suspects there must be some reason.

The reason may find its roots in the continuing unease experienced by most people when they tried to decide whether zoning should be a political process or a professional process. If lay boards are neither fish, flesh, nor fowl, it is perhaps not surprising to find them so deeply engrained in a process that is subject to the same schizophrenia. ${ }^{123}$

Nevertheless, the results of the two studies in this article, taken together, illustrate that the current state of zoning board composition has significant consequences. For example, the prevalence of board members who place a higher value on economic growth than neighborhood and environmental impacts helps explain our inability to control urban sprawl and meaningfully control development. It may explain why gated communities are welcomed in most communities, despite their damaging public impacts. It may explain why high-impact land uses are located most often in poorer sections of town. The exclusion of the "average citizen" from zoning boards does make a difference, it seems, in ways that profoundly affect how our cities develop, which in turn affect the daily lives of the people.

Approaching the 100th anniversary of New York City's comprehensive zoning ordinance, it may be time to reconsider the precise role we want and need appointed citizen zoning boards to play in the planning and zoning process. Robert Walker suggested that there is a natural progression to the integration of new municipal activities: initially, the government may use an independent board to perform these functions, but as they eventually become accepted government duties they

122. Clifford L. Weaver \& Richard F. Babcock, City Zoning: The Once and FUtURE FrontIER 276 (1979) (stating that the most effective way to achieve public interest is "to assure that all the segments of the public having an interest in land use decisions have an opportunity to influence those decisions"); KMIEC, supra note 3, at $\S 4: 4$ (stating that boards have diversified because professional expertise is often accompanied by self-interest).

123. WEAVER \& BABCOCK, supra note 122, at 164-65. 
should be administered by the municipal government itself. ${ }^{124} \mathrm{~A}$ careful re-examination of planning and zoning board activities may result in the reassignment of board duties to different bodies. The function of developing a comprehensive plan, for example, may call for a large group drawn from a broad cross-section of the community, supported by expert consultants, while the detailed review of site plans is a technical process that might be better left in the hands of administrative employees. Inherently political choices, such as zoning amendments, should be decided by elected officials. Short of major reform, however, courts should recognize that zoning boards do not typically represent the average citizen. They may want to reconsider whether deference continues to be appropriate, when the decision-making body is neither neutral nor elected and cannot be properly said to comprise the "proper representatives" of the community. 


\section{Appendix 1}

Survey No.

\section{DRAKE LAW SCHOOL ZONING SURVEY}

Assume you are a member of the planning and zoning commission for your city. This commission is responsible for approving plans for any new land developments in the city. The commission also makes recommendations for zoning changes to the city council.

QUESTIONS 1-3: Major Stores, Inc., has submitted a plan to the planning and zoning commission for a large building supply store (like Menard's or Home Depot) on a piece of land that is now used for agricultural purposes. The proposal will require a zoning change from agricultural to commercial. The site is adjacent to a residential area, built in the 1970's, made up of small, but tidy, houses on relatively small lots. Your commission has heard from many neighbors worried about the additional traffic, noise, and loss of privacy this development would cause. The commission has also heard from city officials who are in favor of the plan, because it will bring additional jobs and economic development to the city.

\section{Please answer the following questions about this proposal:}

1. Would you vote to recommend the zoning change to commercial, in order to allow this development?

DEFINITELY YES PROBABLY YES UNSURE PROBABLY NO DEFINITELY NO

2. The developer must also obtain the commission's approval of its specific plan for developing the site. A neighbor proposes that, as a condition of plan approval, the developer be required to plant trees and bushes or install a privacy fence around the perimeter of the site, to lessen the impact on the neighboring houses. The developer protests that the cost of the screening would be at least $\$ 75,000$ and argues that the new development will not greatly affect neighboring property values. Would you vote in favor of this screening requirement?

DEFINITELY YES PROBABLY YES UNSURE PROBABLY NO DEFINITELY NO 
3. Assume that there is a meandering stream on the site of the proposed building supply store. The stream is lined with trees and provides habitat for wildlife, while also providing some flood and erosion control. The proposed site plan calls for the vegetation, including trees, to be cleared, the stream straightened and turned into a canal, lined with concrete. It is possible that the stream could be left in its original condition, but this would result in a $20 \%$ smaller buildable area, which the developer claims would make the whole project unworkable. Would you vote in favor of requiring, as a condition of plan approval, that the stream be left in its original condition?

DEFINITELY YES PROBABLY YES UNSURE PROBABLY NO DEFINITELY NO

4. Would you favor a requirement that every developer who puts in a new residential housing development be required to dedicate a certain portion of their development as a biking/hiking trail, park, or other public use?

DEFINITELY YES PROBABLY YES UNSURE PROBABLY NO DEFINITELY NO

5. Assume that a developer plans a new "gated community" of expensive houses, called Lakeside, on the edge of a town called Riverton. The gated community will have 100 new homes on large lots and will be located on 200 acres including a private lake and golf course. On the other side of the development is a public walking/bike trail along a river. Because the gated community plans to bar entrance to everyone except residents and their guests, the general public will not be allowed to walk or drive through the community to reach the bike trail on the other side. Instead, Riverton residents will have to travel around the gated community on public roads, which will lengthen their path to the trail by an average of one mile.

Would you be in favor of requiring Lakeside to allow public access to their streets and sidewalks?

DEFINITELY YES PROBABLY YES UNSURE PROBABLY NO DEFINITELY NO

6. Some communities are beginning to require developers to use more sustainable practices. For example, commercial developments may have use special pavement on their parking lots, which allows storm water to seep through rather than run off. Residential developments may use grassy culverts rather than curbs and gutters to catch 
storm water. Would you be in favor of requiring these types of sustainable practices, even if they increase the cost of development by $10 \%$ ?

DEFINITELY YES PROBABLY YES UNSURE PROBABLY NO DEFINITELY NO

7. Assume that a certain district in your town has many buildings, both commercial and residential, built in the 1920s in a particularly attractive architectural style. A developer has bought up several of the properties and plans to take the buildings down to make room for a modern office building. The developer would make several million dollars on this development, whereas the area now has very little income potential. Would you be in favor of declaring this area a historic preservation zone, which would prevent the owner from destroying or making significant changes to these buildings?

DEFINITELY YES PROBABLY YES UNSURE PROBABLY NO DEFINITELY NO

8. Would you be in favor of the historic building restrictions if the owners were compensated by property tax reductions or other incentives for some of the costs of maintaining and renovating these historic structures?

DEFINITELY YES PROBABLY YES UNSURE PROBABLY NO DEFINITELY NO

\section{Please provide the following information:}

OCCUPATION:

RETIRED job before retirement and check here) (if retired, please indicate primary

\section{OCCUPATIONAL CATEGORY:}

Labor

Service

Agricultural

Professional, Managerial, Technical

$\square$ Housewife/husband

Unemployed

Retired (check box above for last occupation) 


\section{HIGHEST EDUCATIONAL LEVEL}

$\square$ Middle school/Jr. High

$\square \quad$ Some high school

$\square \quad$ High School graduate

$\square \quad$ Some college/ assoc. degree

$\square \quad$ Bachelor's degree

$\square \quad$ Masters/PhD/adv. degree

\section{APPROX. ANNUAL GROSS FAMILY INCOME RANGE}

口 UNDER $\$ 25,000$

$\square \quad \$ 25,000-49,999$

$50,000-74,999

$\square \quad \$ 75,000-99,999$

$\square \quad \$ 100,000-149,000$

$\square$ over $\$ 150,000$

RACE/ ORIGIN (if mixed, check all that apply):

$\square$ Caucasian/White

$\square$ African-American/Black

$\square$ Hispanic/Latino

$\square$ Asian

$\square$ American Indian/Alaska Native 
AGE:

ㅁ $18-24$

25-34

35-44

$\square \quad 45-54$

55-64

$\square \quad 65-74$

$\square \quad$ over 75

Do you own or rent your dwelling?

$\square$ Own

$\square$ Rent

$\square$ Other/live with family, friends 


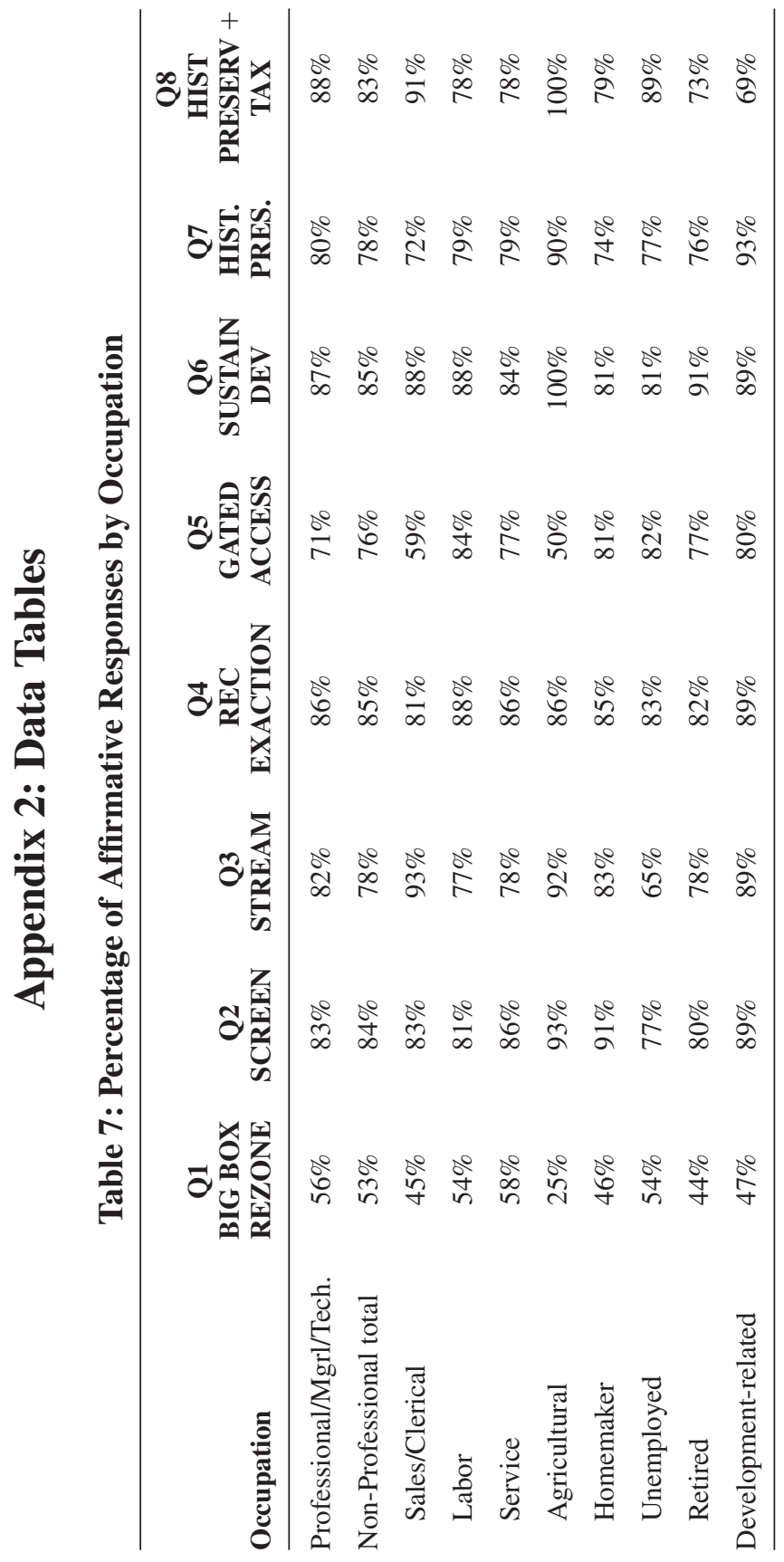




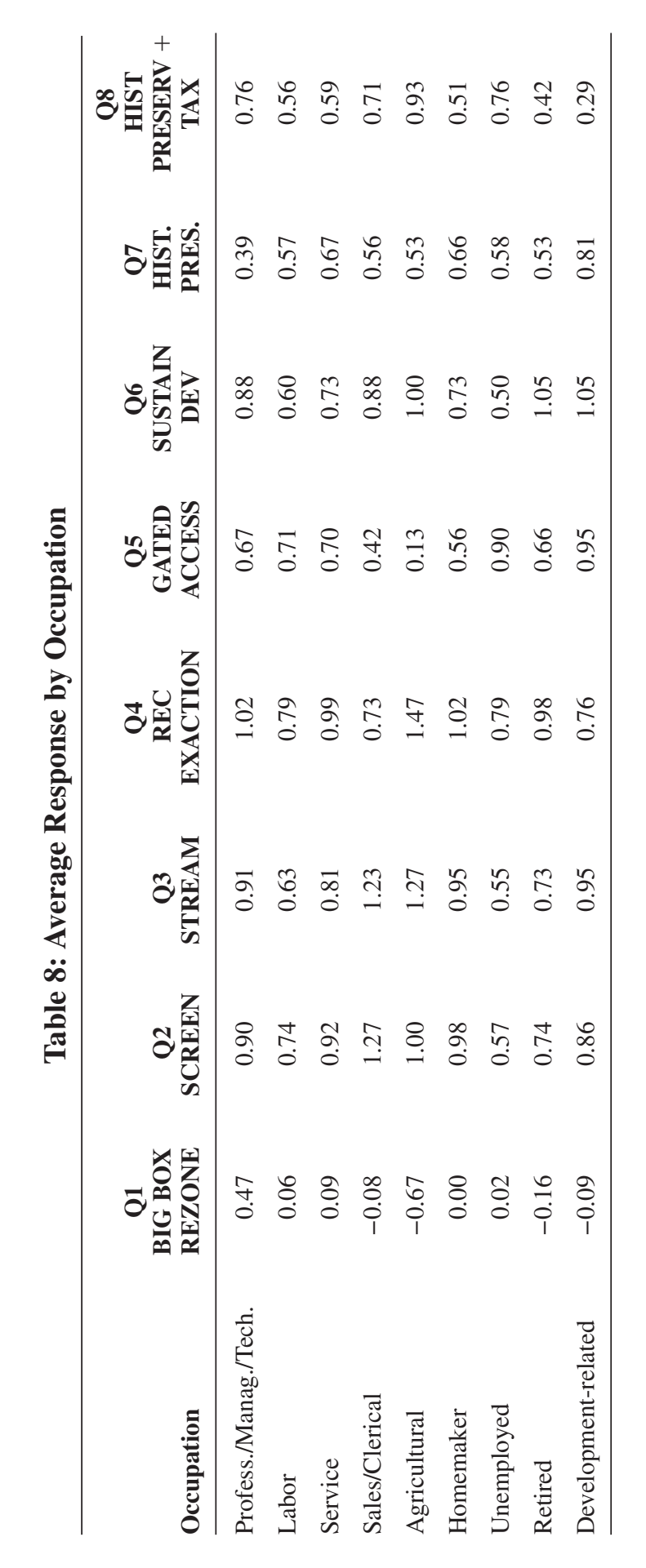




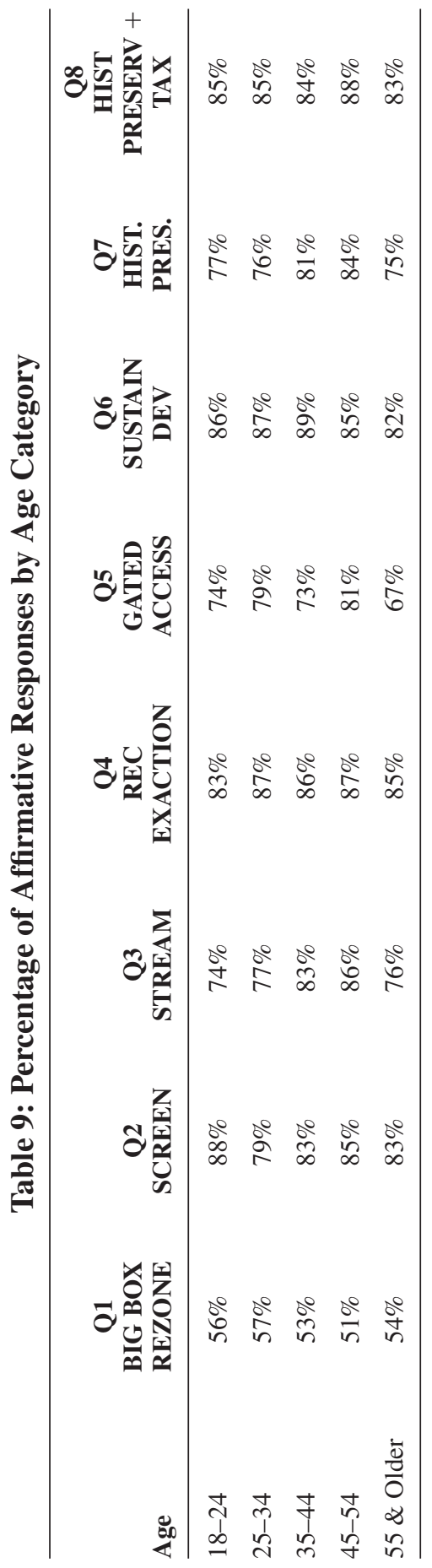




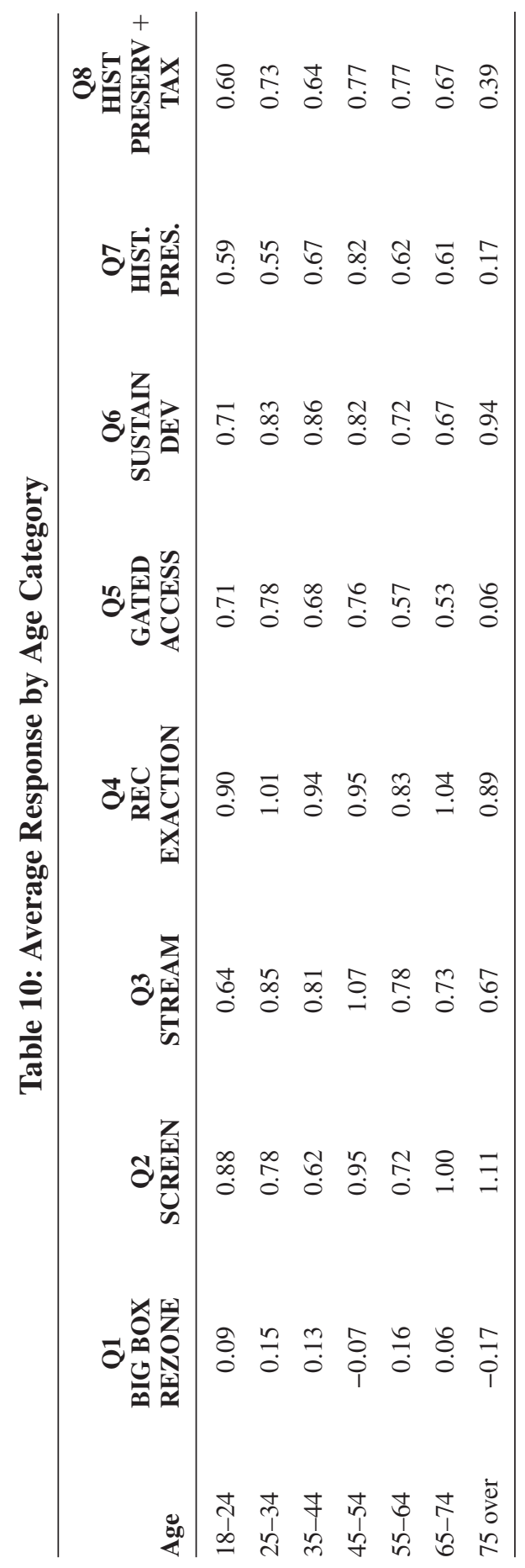




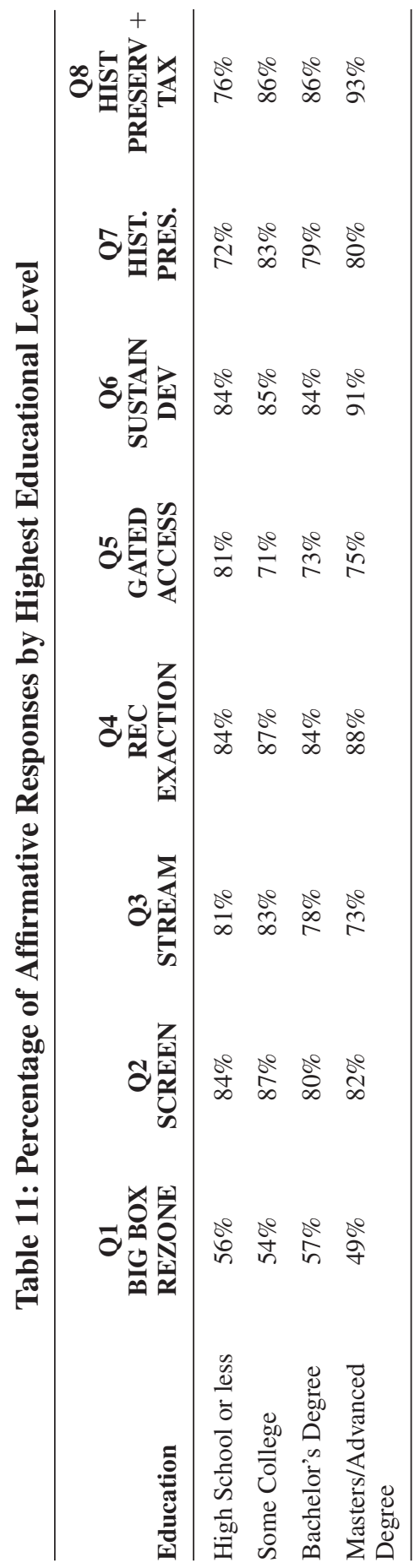




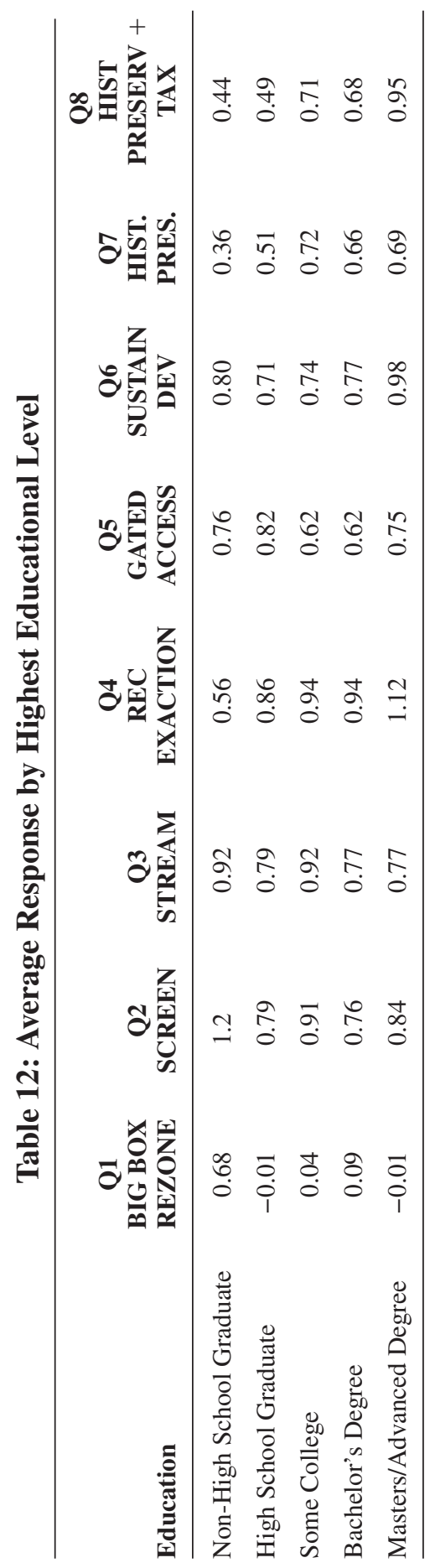




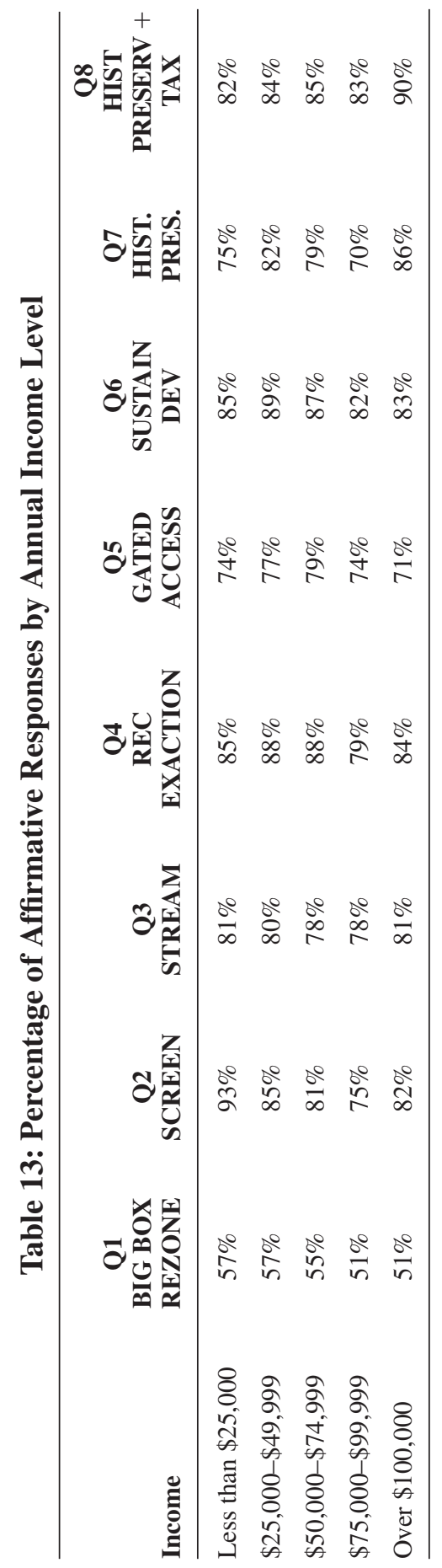




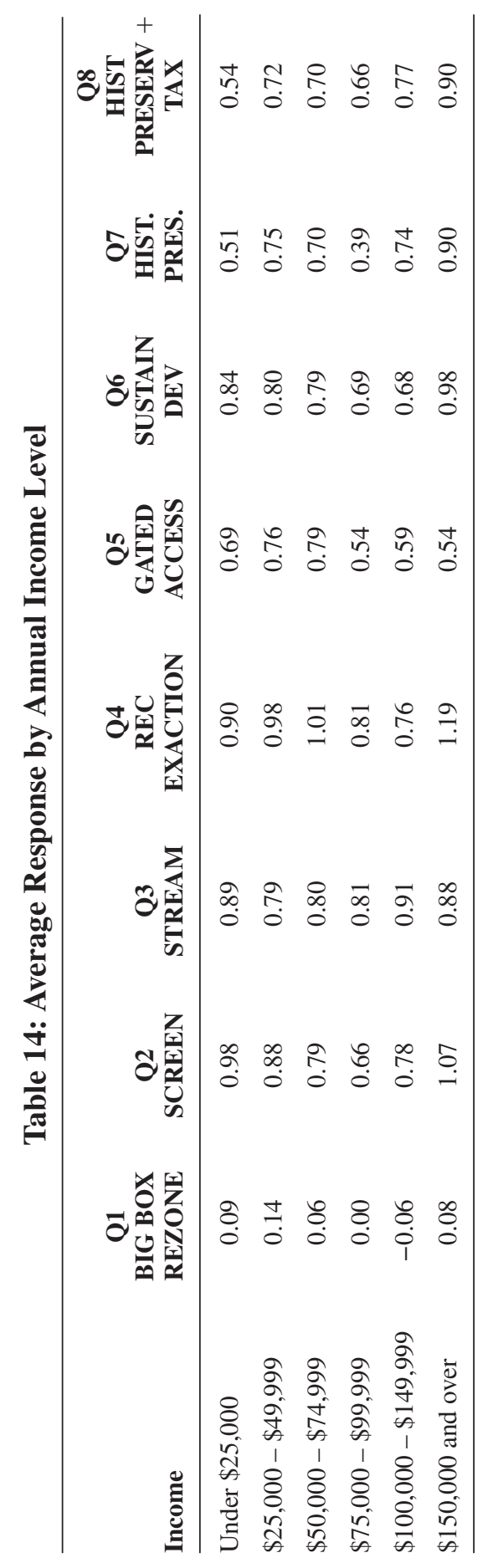




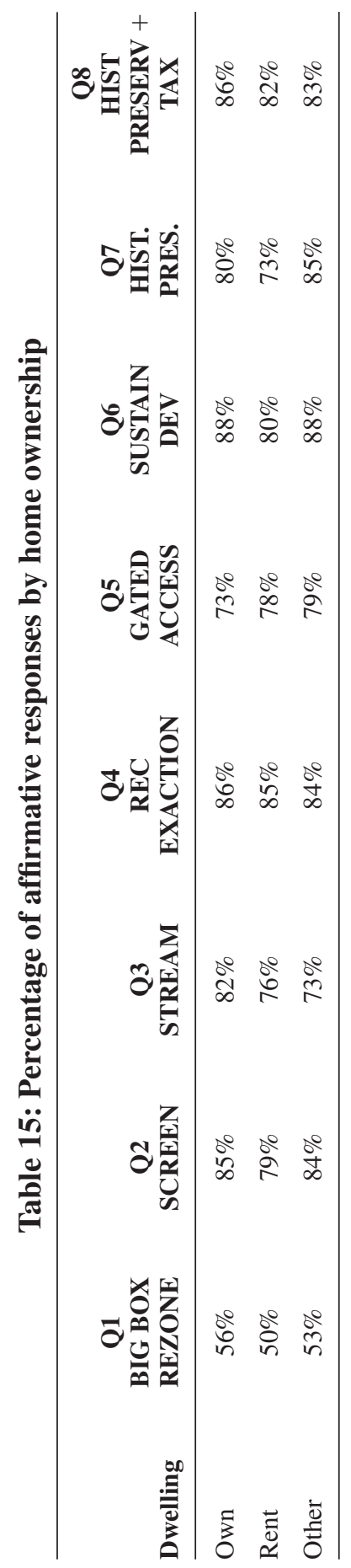




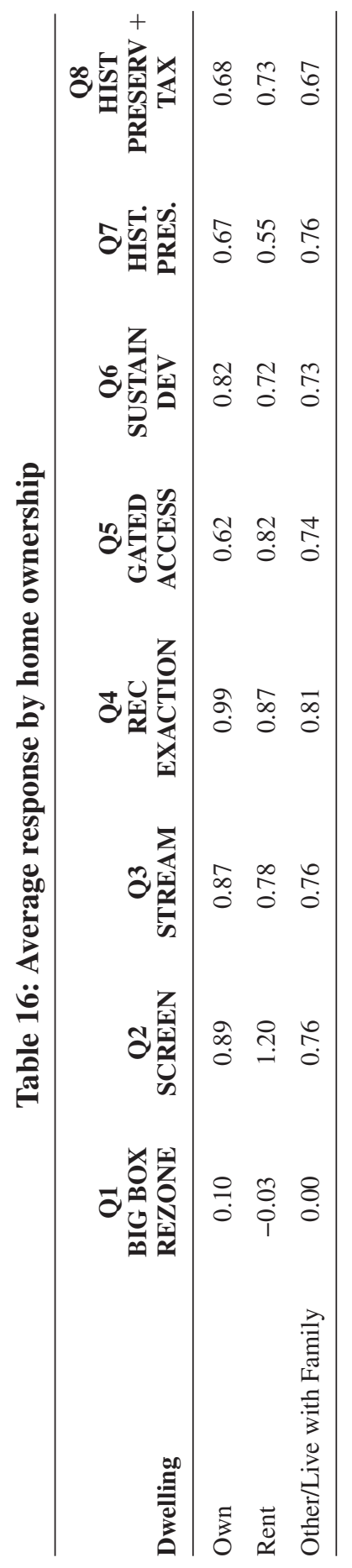




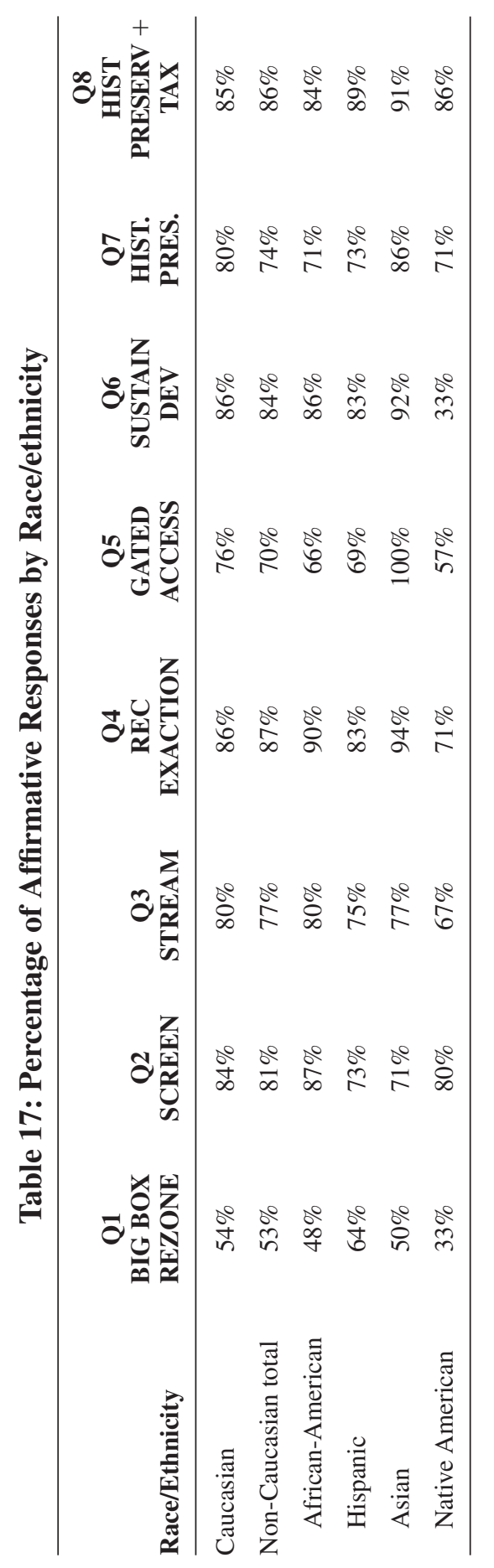




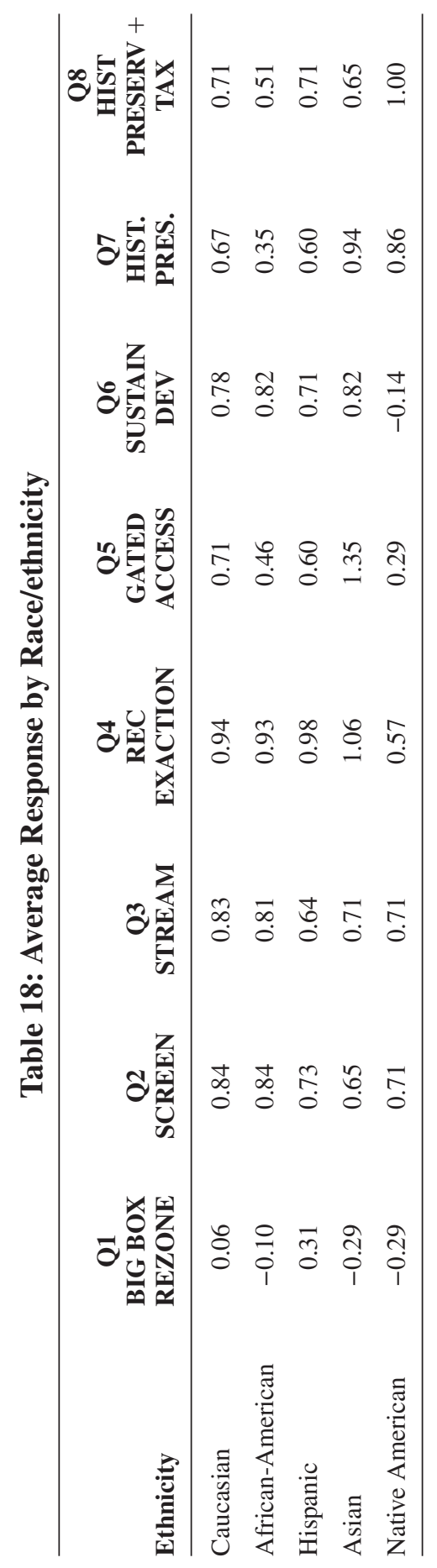


